\title{
Tulane
}

\author{
Tulane Economics Working Paper Series
}

Declining Inequality in Latin America: Some Economics, Some Politics

\author{
Nancy Birdsall \\ Center for Global Development \\ Washington, DC \\ nbirdsall@cgdev.org \\ Darryl McLeod \\ Economics Department \\ Fordham University \\ Bronx, NY \\ mcleod@fordham.edu
}

Nora Lustig

Department of Economics

Tulane University

New Orleans, L

nlustig@tulane.edu

Working Paper 1120

May 2011

Keywords: inequality, poverty, social policy, new left, Latin America

JEL: Keywords: O15, P16, I32 


\section{Declining Inequality in Latin America: Some Economics, Some Politics}

\section{Nancy Birdsall, Nora Lustig and Darryl McLeod* $5 / 9 / 2011$}

\section{Prepared as a Chapter for the Routledge Handbook of Latin American Politics edited by Peter Kingstone and Deborah Yashar}

Keywords: inequality, poverty, social policy, new left, Latin America JEL: O15, P16, I32

\footnotetext{
"Nancy Birdsall is President of the Center for Global Development (nbirdsall@cgdev.org). Nora Lustig is Samuel Z. Stone Professor of Latin American Economics at Tulane University and nonresident senior fellow at the Center for Global Development and the Inter-American Dialogue (nlustig@tulane.edu). Darryl McLeod is Associate Professor in the Economics Department at Fordham University (mcleod@fordham.edu). The authors thank without implicating Jorge Mariscal for help with data, Amanda Glassman for excellent comments, and Pronita Saxena for excellent research assistance.
} 
Latin America is known to be the region of the world where income inequality is among the highest. Its high inequality has been invoked by economists as an explanation for its low rates of growth compared to East Asia, for its poor record on education given its per capita income, and for the volatility of its macroeconomic policies - the best-known example being its governments' periodic recourse to inflationary policies to cope with political demands for greater social justice. ${ }^{1}$ High inequality has also been linked to its long history of political instability, authoritarian regimes and civil strife. Historians attribute its high, persistent and region-wide inequality (in virtually all countries of the region) to its unfortunate past - in which colonial victors exploited indigenous labor or imported slaves to enrich themselves via exploitation of the region's natural resource wealth - its gold, silver, tin, and copper - and its comparative advantage in plantation crops such as sugar. ${ }^{2}$ In a typical tale of the curse of natural resources, the result: a high concentration of income of a tiny ruling elite that had no interest in delivering such basic services as education and health to the poor majority, or in creating institutions of government accountable to the great majority of people.

Thus the prevailing view of economists has been that in much of Latin America, the economics of initial comparative advantage generated a political dynamic that in turn undermined the region's long-run economic potential - and probably slowed the emergence of accountable and responsive democracies as well. Or put another way: Economics explains the politics which explains the economics.

But now new research by economists suggests a change. In the last decade, inequality (and the poverty that has accompanied it) has been declining in 13 of the region's countries (out of 17 for which comparable data are available), including all the larger ones. ${ }^{3}$

\section{[INSERT FIGURE 1 HERE]}

In this paper we discuss the possible causes - economic and political - of these inequality declines, and their implications for whether the trend will be sustained. We first summarize findings on the decline of inequality and its causes. We then present and discuss an assessment of how the type of political regime matters and why. The latter is followed by a brief discussion of the relationship between changes in inequality and changes in the size of the middle class in the region. We conclude with some questions about whether and how changes in income distribution and in middle class economic power will affect the politics of distribution in the future: Will political changes help lock in recent advances against Latin America's longstanding pathology of high and stubborn inequality?

\section{High inequality finally declining: economic and political causes}

Almost all countries in Latin America have high income inequality compared to countries in other regions (with the possible exception of some countries in sub-Saharan Africa, where only a

\footnotetext{
${ }^{1}$ Inter-American Development Bank (1999); Birdsall and Jaspersen (1997); Sachs (1989); Dornbusch and Edwards (1991).

${ }^{2}$ Engerman and Sokoloff (1997).

${ }^{3}$ For a comprehensive analysis of the factors behind this change, see Lopez-Calva and Lustig (2010).
} 
few countries have relatively good data) - and higher than predicted inequality given their income per capita (Figure 2).

\section{[INSERT FIGURE 2 HERE]}

The region's high inequality is due in large part to the very high concentration of income at the top of the distribution. Dropping the top 10 percent of households in income per capita from the distributions in many countries of the region would make their Gini coefficients similar to that in the United States (Figure 3). ${ }^{4}$ Moreover, inequality in the region and its concentration at the top is likely to be even higher than that measured in household surveys, both because of underreporting of income especially at the top (Hilgert and Szekely, 1999; Alvaredo and Piketty, 2010) and because most household surveys collect primarily labor income, not property income or income from financial assets. ${ }^{5}$

\section{[INSERT FIGURE 3 HERE]}

Inequality did decline in some countries of the region during the good years of the 1970s, prior to the debt crisis and lost decade of the 1980s. But inequality rose in the tough years of the 1980s; Lustig (1995) reports that in most countries the share of income of not only the bottom but of the middle as well fell, while the share of the top ten percent grew. And inequality continued to rise in the 1990s as most economies recovered (Gasparini and Lustig, 2010).

Regarding the impact of market-oriented reforms on inequality, a detailed review of this vast literature goes beyond the scope of this paper. Morley (2001) does such a review and concludes "...that work shows that the recent ${ }^{6}$ reforms have had a negative but small regressive impact on inequality mainly because many of the individual reforms had offsetting effects. Trade and tax reform have been unambiguously regressive, but opening up the capital account is progressive." Better management of macroeconomic policies - fiscal, monetary and exchange rate - was a good thing for growth and for reducing poverty, the latter since the poor were badly hurt by earlier bouts of inflation and frequent economic crises. ${ }^{7}$ But this consensus is about the benefit of ending inflation for the poor; on the effects of the Washington Consensus policies on inequality there is less agreement. .

The decline in inequality across most countries since the early 2000 s thus has the markings of a breakthrough. The decline has been measurable and substantial in economic terms in at least ten countries with different political systems and styles and approaches to social policy - including

\footnotetext{
${ }_{4}^{4}$ According to the Inter-American Development Bank (1999), the Gini for 90 percent of the population in Latin America would be, on average, only 0.36 instead of 0.52 , and in six countries income inequality would be less than that of the United States. The Gini coefficient takes values between zero (no inequality at all) and one (maximum inequality). Measured at the country level, Ginis tend to be between .25 (Sweden) and .60 (Brazil and South Africa). The Gini coefficient in the United States was about 0.34 in 1996.

${ }^{5}$ Household data on wealth are rare for countries in Latin America and other developing countries. The distribution of wealth is everywhere more unequal than the distribution of income (Davies et al., 2006).

${ }^{6}$ Recent here refers to the 1980s and 1990s, depending on the country.

${ }^{7}$ On effects of macroeconomic policies on the poor via crises, see Lustig (2000).
} 
Argentina, Bolivia, Brazil, Chile, El Salvador, Mexico, Peru and Venezuela. Inequality declined in countries that enjoyed high growth thanks to a benign external environment (with higher commodity prices and lower interest rates) such as Argentina, Chile and Peru and in countries where economic growth was lackluster such as Brazil and Mexico. ${ }^{8}$

As shown in the country studies for Argentina, Brazil, Mexico and Peru included in LopezCalva and Lustig (2010), two key factors have mattered: the decline in the premium to skills (in effect to higher education') and more active and progressive social policies including targeted spending in the four countries (in particular, in Argentina, Brazil and Mexico) benefiting a large proportion (as high as two thirds in Mexico ${ }^{10}$ ) of households at the bottom of the income distribution (households with income per capita below US $\$ 2.50$ a day). ${ }^{11}$ The decline in the premium to skills seems to be mainly the result of the expansion of basic education during the last couple of decades ${ }^{12}$ it might also be a consequence of the petering out of the one-time unequalizing effect of skill-biased technical change in the 1990s associated with the opening up of trade and investment. In any case, in the race between skill-biased technical change and educational upgrading, in the past ten years the latter has taken the lead. ${ }^{13}$

In some ways those are proximate causes of the decline; non-economists might justifiably ask about the political dynamics underlying the greater access to higher levels of education and the progressive social policies.

Consider first education. Acemoglu and Robinson (2010) notes that in the mature Western economies, the expansion of education in the $19^{\text {th }}$ century followed democratization and its consolidation (Lindert and Williamson, 2001 and Lindert, 2004, make that case for the United States). Of course democratization in currently advanced economies can also be associated with other changes that have not historically been associated with inequality decline in Latin America, such as increases in the share of wages in national income (which Rodrik, 1997 shows tend to follow democratization), and the creation of labor market institutions including unions that are associated with that rise in wage share. ${ }^{14}$ In contrast, in the cases of Mexico and Peru, the decline in inequality has coincided with a period of weakening labor market institutions.

\footnotetext{
${ }^{8}$ Brazil and Mexico's per capita GDP growth rate until 2007 were below 3 percent.

${ }_{9}$ On the extraordinary rise in the wage premium to higher education in Latin America in the 1990s, see Behrman, Birdsall and Szekely (2007).

${ }^{10}$ See Lustig, Pessino and Scott (2011).

${ }^{11}$ For more on economic causes, see Lopez-Calva and Lustig (2010) and the contributors to the volume Declining Inequality in Latin America: A Decade of Progress?

12 Basic education includes grades 1-9 in Argentina and Mexico; 1-8 in Brazil; and 1-11 in Peru. The number of grades includes what countries call basic primary and secondary education.

13 Tinbergen (1975) was among the first to use this expression and, more recently, it was the central theme of Goldin and Katz's illuminating analysis of the United States (Goldin and Katz 2008).

${ }^{14}$ Latin America has had active unions, especially in the public sector, but these have tended to increase the dual structure of the labor market, leaving those in the informal sector farther behind and increasing wage inequality overall. In the cases of Mexico and Peru, the decline in inequality coincided with a period of weakening labor market institutions. However, the decline in inequality in Argentina may well be the result of a pro-union/pro-disenfranchised government stance at least in part (Pages et al, 2008).
} 
At the same time, it may be that what political scientists refer to as "consolidated democracy" is still far off in much of Latin America - including Peru, Bolivia, and certainly Guatemala. Instead increasing access to education, at least at the primary and secondary level, could be viewed as a long-term trend common throughout the region and indeed throughout the developing world. That would suggest that it is not primarily democratization that increased education (indeed the increasing trend persisted during the 1980s military period in Brazil, Chile and Argentina) but the participation of Latin America in a worldwide trend reflecting changing global norms in the post-World War II period. In terms of increasing access to schooling, Latin America has not been, over the past 50 years, exceptional; until 1995, schooling increased faster and schooling inequality declined faster in less democratic Asia and even in Africa's weak democracies, schooling access has increased remarkably in the post-war era (Clemens, 2004). In Brazil and Mexico, there was a push for basic education especially in the second half of the 1990s and in Mexico, between 1992 and 2002 spending per primary school student rose by 63 percent. ${ }^{15}$ In addition to "enlightened leadership," this big push for education was possible because of the demographic transition: fewer and fewer children have been entering into primary school because of how the age pyramid has been shifting. However, those who benefited from the new priority on education are of course only now becoming adults and entering the labor force, so any effect on wage inequality of resulting shifts in returns to skills is in the future.

\section{[INSERT FIGURE 4 HERE]}

What about the political dynamics behind the targeted transfer programs? The first largescale of these began in Mexico in the late 1990s with PROGRESA (later called Oportunidades) and spread to other countries later in that decade and especially in the 2000s. Robinson (2010) asserts that "the spread of programs such as PROGRESA in Mexico is clearly related to the democratization that took place in the 1990s, which shifted political power away from corporatist groups like labor unions toward rural voters", citing Scott 2008. He also suggests this and other redistribution programs are more likely where the poor beneficiaries for one reason or another become politically organized - so that even where clientelism still dominates (i.e. democracy is still not fully institutionalized) politics begins to benefit them directly. He contrasts the situation after the year 2000 in Brazil and Bolivia to that in Guatemala. The redistribution program Bolsa Familia in Brazil was instituted nation-wide when a political party reliant on votes by the rural as much as urban poor, the PT (party of workers) under the leadership of Luis Ignacio "Lula" da Silva won the 2000 presidential election. (It was a PT governor that started such a program in the federal district of Brasilia in the 1990s.) In Bolivia, policies of redistribution took hold in 2005 when the rural party movement (the MAP) led to the election of Evo Morales. Political parties are, in short, critical in allowing the poor to solve the collective action problem they face in being adequately represented; otherwise even where they are a clear majority of citizens and even of voters, they will not influence policies that affect the distribution of income.

\footnotetext{
${ }^{15}$ Esquivel et al. (2010) Spending for tertiary education also rose, but for the first time in the 1990s, it rose less than spending for basic (primary and secondary) education.
} 
In short, a long-run increase in access to education which finally, as the supply of educated workers began to catch up with demand brought down what had been high returns to those most skilled; growth in some of the countries (even though still heavily commodity-based); and more progressive government spending came together after the year 2000 to reduce longstanding inequality. ${ }^{16}$ In a number of countries (but not in all) the new influence of political parties representing the poor may be what explains this shift in government spending -- these came together after the year 2000 to reduce longstanding inequality in most countries of the region.

But we also want to suggest there is more to the story.

\section{Declining inequality and leftist regimes: What really matters?}

Inequality declines in the region coincided with the election of leftist regimes starting with the 1999 election of Hugo Chavez in Venezuela and the 2000 victory of Ricardo Lagos in Chile. These elections were followed by 2003 victories of Néstor Kirchner in Argentina and Luiz Inácio "Lula" da Silva in Brazil. This swing to left was repeated in Uruguay, Bolivia, Ecuador and Nicaragua where candidates promising a radical break with past neoliberal policies won elections in 2006 and 2007. And it continued in Paraguay (2008) and El Salvador (2009). This section reviews the criteria political scientists and economists have used to distinguish populist from non populist new Latin left regimes and provides some evidence of the efficacy and sustainability of redistributive policies.

The regimes classified as "new left" have accumulated some 34 effective policy years across eight countries, governing at one point about $2 / 3$ of the region's population. Using the consistent survey based inequality estimates prepared by SEDLAC for 18 countries in the region covering the period from 1988 to 2008, we evaluate inequality changes for three political regime groups: left populist, social democratic and non-left governments, ${ }^{17}$ focusing mainly on public social spending on transfers, education and health ${ }^{18}$ as both a measure of political will and as a key redistributive mechanism. ${ }^{19}$ Our analysis builds on Lustig and McLeod (2009) and McLeod and Lustig (2010), who show that both types of left regimes boosted social spending and reduced inequality during the decade ending in 2009, especially compared to the non-left regimes. However, the left populist group led by Argentina and Venezuela has largely just managed to bring inequality down to pre-crisis

\footnotetext{
16 See Barros et al. (2010), Esquivel et al. (2010), Gasparini and Cruces (2010a, 2010b), Gray-Molina and Yañez (2009), Jaramillo and Saavedra (2010).

17 The populist left regimes include Argentina, Bolivia, Ecuador, Nicaragua and Venezuela; the social democratic left include Brazil, Chile and Uruguay; the non-left countries include Colombia, Costa Rica, Dominican Republic, El Salvador, Guatemala, Honduras, Mexico, Panama, Paraguay and Peru. The classification by regime type is based on Arnson and Perales (2007). (See also Table 1) We are not political scientists and make no explicit claims ourselves about the classifications. In the regression analysis, the populist left is comprised of Argentina, Bolivia, Ecuador, and Venezuela. Note that in the econometric analysis, Nicaragua is included among the non-left regimes because the available data end in 2006, before the leftist government took power. The same applies to El Salvador and Paraguay where the available data do not correspond to when the left took power.

18 As estimated and assembled by CEPAL (Gasto Público Social).

${ }^{19}$ We rely on the excellent standardized survey based inequality estimates assembled by SEDLAC (Socio-economic Database for Latin American and the Caribbean, CEDLAS and the World Bank) 1989 to 2008. sedlac.econo.unlp.edu.ar
} 
levels. Brazil and Chile on the other hand lowered inequality to historic lows during this period, lowering their respective Gini coefficients by a full six and three percentage points, respectively (see Figure 5 below). In addition, though macroeconomic indicators of external and internal balance of all the Latin America's new left regimes are benign by historical standards, since 2007 inflation in Argentina and Venezuela has risen into double digits fueled by a rapid expansion of domestic credit, perhaps an early indication of unsustainable redistributive policies.

\section{[INSERT FIGURE 5]}

Table 1 classifies the various "new left" regimes that have come to power in Latin America since the turn of the century. Though a common denominator in the rhetoric of these regimes was rejection of previous "neoliberal" or market oriented policy regimes, over time differences emerged in the methods and economic policies of these regimes. Kaufman (2007) distinguishes between “... parties that combine distributive goals with market oriented policies and those advocating a return to more traditional forms of state control and economic nationalism". ${ }^{20}$ Dornbusch and Edwards (1991) famously characterize "economic populism” as “. ... an approach to economics that emphasizes growth and income distribution and deemphasizes the risks of inflation and deficit finance, external constraints, and the reaction of economic agents to aggressive nonmarket policies." (p. 9) Similarly, Edwards (2009) argues that left governments in Brazil, Chile and Uruguay have found a way to marry laudable redistributive policies with sustainable market oriented economic policies, while the "left populist" regimes listed in Table 1 have not. Over time Edwards (2009) argues this difference will be manifested in slower growth and ultimately ineffective redistributive policies. ${ }^{21}$

\section{[INSERT TABLE 1]}

From a political point of view, the fear is that the left populist regimes have become too sustainable, tampering with institutions and electoral systems in ways that work to extend their hold on power indefinitely. Arnson and Perales (2007) for example note that in Brazil, Chile and Uruguay "left parties have moderated over time and participate fully in stable, competitive electoral systems", while under populist regimes in Argentina, Bolivia, Ecuador , Nicaragua and Venezuela the "political system is 'refounded' via new constitutions that strengthen the executive at the expense of checks and balances" and where the political discourse is highly polarizing between 'the people' and an oligarchic elite. And where "new forms of political participation are created outside traditional institutions, such as parties, and are linked to the president in corporatist fashion, the state intervenes in the economy in ways that are hostile to private capital, etc. Similarly, Roberts, Bethell and Mayorga (2007) see the social democratic regimes of Brazil, Chile and Uruguay as "the maturation of democracy" but see recent political developments in Venezuela and Bolivia as "not the maturation of democracy, but rather its crisis: namely, the failure of representative democratic

\footnotetext{
${ }^{20}$ Kaufman cites p.24 in Arnson and Perales, 2007.

${ }^{21}$ Edwards (2009) also classifies Alan Garcia's regime in Peru as social democratic; others might reasonably classify Fernandez' regime in Dominican Republic as social democratic.
} 
institutions to respond effectively to social needs and demands." In "Argentina, Peru, Venezuela and Bolivia populist or leftist leaders operate in political systems where opposition parties have virtually evaporated, and representative institutions are struggling to rebuild." Similarly, Acemoglu et al. (2010) see the rise of left populist governments with charismatic leaders and "left of median voter" policies as a response of electorates that are convinced that corruption and existing checks and balances allow elites to capture governments thereby preventing promised redistribution toward the middle class: voters choose radical populist leaders precisely because they promise to dismantle traditional checks and balances.

There is some evidence that the new century's left regimes (both types) have reduced inequality in Latin America more than non-left regimes (see Lustig and McLeod, 2009; Cornia, 2010; and, McLeod and Lustig, 2010), and that within the left regimes, that it is the social democratic regimes that have done better. Table 2 presents estimates from Lustig and McLeod (2009) using the cumulative years in power index for each regime presented in Table 1. The key result is that though both regimes reduced inequality and poverty during the past decade, once one controls for unobserved factors (fixed effects) or initial levels of inequality, only the social democratic regimes appear to break with the past, reducing inequality to historic lows.

\section{[INSERT TABLE 2]}

What made the difference between the two types of leftist regimes? An obvious possibility is their macroeconomic policies. Columns II and III of Table 2 suggest that underlying factors associated with left populist regimes, including higher inflation, may underlie their lesser success in policy terms in reducing inequality. But the differences in key macroeconomic indicators between the two types of leftist regimes have not been all that great in the last decade. Inflation though higher since 2000 in the populist regimes, has been far below rates in the 1980s (Appendix Table A.1). (Inflation in the social democratic regimes has been even lower than in the non-leftist regimes; the social democratic left has been conservative not only relative to the past but relative to the right.) The populist left regimes enjoyed better terms of trade and also had higher fuel exports as a percent of merchandise trade. But as with inflation the differences are not dramatic - except possibly for Argentina and Venezuela in just the last couple of years. For much of the decade, left populist regimes ran healthy primary surpluses (though lower than in social democratic regimes) and they managed to reduce their external debt to GDP ratios to below 20 percent. ${ }^{22}$ As a result it is hard to attribute the differences in the success of the two types of leftist regimes in reducing inequality primarily to differences in their macroeconomic policies - at least up to now. (Of course to the extent these favorable conditions constitute an ongoing boom the question is whether the growth and inequality reduction (and poverty reduction) the populist regimes have enjoyed can be sustained if and when those conditions change). ${ }^{23}$

\footnotetext{
22 Appendix Table A-1.

${ }^{23}$ The classic populist response to favorable terms of trade is external borrowing and capital inflows which make a boom unsustainable. In early 2010 there is little evidence of excessive external borrowing or capital inflows.
} 
More important than macroeconomic indicators to explain the difference between the two types of leftist regimes are two other factors. First have been changes in social policy, including social spending. Cornia (2010) suggests that a wide range of social and redistributive policies, ranging from social spending to minimum wage increases, have reduced inequality in all countries. Have the two different types of left regimes been different in their social and other redistributive programs and policies? Figure 6 portrays estimates by the two types of left regimes of the annual redistribution of household income across quintiles in the last two decades. ${ }^{24}$ These estimates show much greater redistribution from richer to poorer in the social democratic regimes. Social democratic regimes basically ignore the fourth quintile, whose income share is remarkably constant, but redistribute about 0.4 percent of GDP each year in office from the top quintile to the bottom three quintiles. For the left populist regimes there has not been much change in the quintile shares from in the early 1990s, (though there is certainly improvement compared to the crisis years of the late 1990s (2001 in Argentina)). This result is not consistent with the usual characterization (e.g. Acemoglu et al.) of populist political movements as "left of the median voter" policy regimes, implying the poorest groups may benefit most (and this is certainly the rhetoric of left regimes).

\section{[INSERT FIGURE 6 AND 7]}

What was the role of social policy in the social democratic regimes in effecting this greater redistribution? There is considerable evidence from household surveys that education expenditures and conditional cash transfer programs have reduced inequality and poverty. Is that what mattered at the national level, and more so in the social democratic regimes? As Table 2 above indicates, public social spending had an equalizing effect in the region overall (and total government spending a disequalizing effect). ${ }^{25}$ But our sample by regime type is too small to directly estimate differential effects of social and other spending. To address the question, we first plot changes in social spending (as a share of GDP) for the three types of regimes, focusing on the early and largest social democratic and left populist regimes in Figure 7. Both Chile and Brazil (mainly the latter) increased public spending on transfers, education and health ${ }^{26}$ during this period, according to CEPAL. Though data for Venezuela are not available after 2006, the left populist regimes also allocated considerably more than non-left governments to social spending but less than the social democratic regimes.

We then do fixed effects estimates of changes in the share of social spending in total government spending across quintiles for the period 1990-2008, this time by type of regime (Figure

\footnotetext{
${ }^{24}$ See also Appendix Table A-Z.

${ }^{25}$ Social spending was greater in social democratic than populist left regimes throughout the past decades (and greater than in non-left regimes), but so was overall government spending - with presumably offsetting effects on inequality in each regime. Appendix Table A-1.

26 As estimated and assembled by CEPAL (Gasto Público Social) available at http://www.eclac.org/.
} 
8). ${ }^{27}$ Social spending is progressive across all regime types, but is most progressive in the social democratic regimes, with redistribution again (as with overall income) from the top to the bottom three quintiles. This result is consistent with both spending on cash transfers targeted to the poor in the bottom quintile, but also with greater increases in spending on health and education that reach the lower and middle quintiles (probably in most countries compared to changes in the proportion spent on pensions), and within those sectors, probably greater increases on basic services - in education with greater increases in spending on primary and secondary schooling than on public universities.

\section{[INSERT FIGURE 8 HERE]}

The second factor by which the two types of leftist regimes differ sharply is in indicators of transparency and government effectiveness (including as viewed by outside investors). One example is the understatement of Argentina's inflation by its official agency (INDEC). In 2007 several staff members of INDEC were fired and for the next three years Argentina's official inflation rate stabilized at about 8 percent, while other estimates (e.g. the independent FIEL) put inflation over 20 percent in 2008-2010 (see below). ${ }^{28}$ And of the five left populist regimes only Venezuela reports its primary deficit to the IMF.

Differences in transparency are not well measured across countries. However there are various measures of government effectiveness. Figure 9 reflects the scores of countries in the region by regime type reported by Kaufman, Kraay, and Mastruzzi (2008) - in turn based on views expressed within countries by measuring perceptions of the quality of public services, the quality of the civil service and the degree of its independence from political pressures, the quality of policy formulation and implementation, and the credibility of the government's commitment to such policies through surveys of a range of stakeholders (firms, individuals, NGOs, commercial risk rating agencies, multilateral aid agencies, and other public sector organizations). The left populist regimes are rated considerably below the non-left regimes, and the social democratic regimes are rated well above. ${ }^{29}$ Brazil, Chile and Uruguay are considered more effective governments overall.

\section{[INSERT FIGURE 9 HERE]}

Finally we ask whether the reductions in inequality in the new left regimes of Latin America are permanent or transitory? Historically, populist policies have been financed by favorable terms of trade shifts that provide the public revenues needed to finance redistributive programs (until the commodity price boom ends). ${ }^{30}$ The current era is no exception. As shown in Figure 10, terms of trade have treated both the populist and social democratic regimes well, especially compared to other non-left Latin countries. (Appendix Table A-1). Chile and Venezuela experienced the most

\footnotetext{
27 The regression on which the figure is based is shown in Appendix Table A-2.

${ }_{28}$ The IMF prints Argentina's official inflation with a footnote saying private estimates put inflation considerably higher, and recently Argentina asked for and is getting technical assistance from the IMF at INDEC.

29 A similar assessment from Moody's tells a similar story (available from the authors). Moody's is not, of course an unbiased observer of Latin regimes but whatever its bias there are real consequences in terms of lower credit ratings.

30 The classic example is first Peron regime in the early 1950s, Dornbusch and Edwards (1991).
} 
dramatic improvements in their terms of trade, as high petroleum and copper prices added directly to government revenues. The improvements in Brazil's terms of trade have been more modest, as shown with the population-weighted terms of trade index, dominated by Brazil (Argentina and Venezuela are similar in size so the population-weighted terms of trade index is not much different than the simple average shown in Figure 10 (and Appendix Table A-1). Improvements in the terms of trade have had a progressive impact at least in the short term, but cannot explain much of Brazil's reduction in equality; as shown in Table 2, controlling for the terms of trade it is the political regime that made a difference.

\section{[INSERT FIGURE 10]}

Apart from transient commodity price booms, what can make redistribution unsustainable are macroeconomic imbalances, particularly the accumulation of internal public sector or external debt. In this regard both types of left regimes have been relatively conservative, paying down external debt (see Table A-1) and avoiding large fiscal deficits (in fact by most measures the social democratic regimes have been more conservative that non-left regimes, perhaps as a way to boost their credibility with the private sector). A worrisome trend, however, is the recent expansion of domestic credit and the recent double digit rates of inflation in Argentina and Venezuela. In the short term, inflation can undermine efforts to redistribute income as the inflation tax is regressive (we present some evidence of this below). Over the longer term high inflation fueled by domestic credit growth can lead to exchange rate appreciation and capital flight, though at the moment both countries are running current account surpluses (due in part to high commodity prices).

In short, during the first decade of the $21^{\text {st }}$ century, our econometric evidence suggests that though inequality fell in most leftist regimes, those with left populist governments were more likely to benefit from good luck than good policy, including increases in the prices of oil and other commodities, while those with social democratic regimes reduced inequality more than they would have otherwise because of good policy - including effective redistribution programs. The difference does not appear to have been dramatically better macroeconomic management, at least as reflected in traditional indicators. We do not have enough data over enough periods to estimate directly the impact of inflation, government spending and other variables on inequality for each of the three regime types. But the descriptive data suggest the differences between the two leftist regime types as measured by traditional macro indicators have until very recently been small - perhaps because the external environment has made reasonably "good macro" relatively easy.

Instead the difference between the two types of regimes appears to have more to do with the elusive quality of "government effectiveness" as seen by observers, including in the type of and management (not the amount) of social spending. On that score it could be observers (particularly private investors) are noting the success of Chile in adhering to its fiscal rules and the political support for Lula's inflation fighting in Brazil; but it also could be that the social democratic governments are also seen as more efficient and effective as managers of social and other expenditure programs. 
It would be ironic if governments in Latin America were more successful in reducing inequality because they are more effective at managing such social programs as conditional cash transfers - and are simultaneously viewed as more reliable and business-friendly. At the same time, insofar as private investors also view macroeconomic stability as a key indicator of government effectiveness, it appears that the inequality declines in the social democratic regimes are more likely to be sustained in the future than the declines in the populist regimes.

\section{Declining Inequality, the Middle Class and Politics}

How might changes in the size and economic command of the middle class change the politics of distribution in Latin America? Might the history of political power being controlled by a landed elite and industrialists with little interest in expanding economic opportunity change where the middle class is growing, at least in democratic regimes? Where clientelist politics have led to populist economic programs, consistent with median voter theory, might a larger middle class encourage more fiscally sustainable while still stable and progressive policies?

Birdsall (2010) defines a global middle class in income terms across both advanced and developing countries as those households with income per capita of at least $\$ 10$ (2005 PPP terms) who are not among the richest 5 percent in their own country. This "indispensable" middle class is likely to demand capable and accountable government and economic policies conducive to marketled growth.

The relatively high $\$ 10$ floor means that in developing countries the global middle class tends to be concentrated in the top quintiles of the income distribution. In the lowest-income countries, for example in Africa, by this definition there was no middle class at all in 2005_all households enjoying per capita income of at least $\$ 10$ were in the excluded top 5 per cent of the income distribution.

In Latin America, the middle class so defined consists entirely of households in the top quintile in all countries studied, except Mexico, urban Argentina, and Chile (Figure 11).

\section{[INSERT FIGURE 11 HERE]}

By this definition, the size of the middle class as a proportion of the population in 2005 ranged from 7 percent in Honduras to 33 percent in Chile; the proportion of total income commanded by the middle class ranged from 14 to 42 percent (in 2005, middle class size in the United States and Sweden were 91 and 95 percent, respectively, and their shares of income were 81 and 88 percent, respectively).

Three countries in the region showed the largest increases in the global middle class by the two measures between 1990 and 2005: Brazil, Chile and Mexico -- two social democratic regimes and one non-left regime, consistent with the inequality declines in those countries noted above. Our analysis of changes in quintile share per capita growth elasticities by political regime in almost the 
same period (see Appendix Table A-3) indicates that in the social democratic regimes where the middle class grew, it grew despite the fourth and fifth quintiles capturing much less of the benefits of growth (indeed the fifth or richest quintile's elasticity of per capita growth to overall growth is negative) than did the lower three quintiles. Incomes at the top of the distribution (which are absolutely higher to start with) grew far less than incomes at the bottom in these social democratic regimes - and more so than in the populist left regimes. But they did grow, so that more people crossed beyond the $\$ 10$ per day line and entered the middle class, as overall incomes rose in those countries. $^{31}$

Meanwhile two left populist countries by 2005 had suffered absolute declines in the size of their middle classes by 2005: Venezuela (where the middle class fell from 21 to 3 percent of the population, and its proportion of income from 35 to 8 percent) and urban Argentina (survey in Argentina covered urban areas only) where the middle class fell from 39 to 31 percent and its proportion of income from 53 to 46 percent). The declines in inequality reported for those countries by 2008 are likely to be associated with declines in income overall, and relatively greater declines in the incomes of households in the top two "middle-income" quintiles, where the middle class (by the $\$ 10$ per day definition) is concentrated. ${ }^{32}$

Might the growing middle classes in countries like Chile and Brazil help lock in leftist social democratic political regimes (whether because or despite its concentration in the top quintile of households)? There is no evidence that a large middle class is necessary let alone sufficient to these regimes. But a growing global middle class does seem likely to reinforce effective government that manages moderate redistribution while retaining investor confidence in the likelihood of continuing growth and price stability.

Put another way: When is the middle class large enough to become politically salient in supporting or at least tolerating the kind of social and other distributive policies that are good for them but turn out to be good for the poor-for example universal public education? When is the middle class status' potentially attainable to the median voter so that he or she votes for the regime type that represents "middle class" interests? The numbers above, which say nothing about the causal effect of a large middle class size on the type of political regime, suggest the answer in Latin America is not yet but getting close in Chile and Mexico, and possibly in Brazil as well. At the same time, considering causality in the other direction, it does appear that social democratic regimes are good for growing the middle class - as growth itself increases household income in the third and fourth quintiles - and politics permits that relatively more of the benefits of that growth are shared at the bottom of the distribution.

\section{Conclusion: Some politics, some economics}

\footnotetext{
${ }^{31}$ In a country like Brazil, by this definition (a minimum of $\$ 10$ per day per capita), all members of the middle class were in the top quintile. With overall growth, households in the fourth quintile moved over the $\$ 10$ day line into the middle class.

32 Because the middle class defined in Birdsall, 2010 is not the middle stratum it is possible to have a growing middle class and increasing inequality -- the case for Bolivia, Colombia, and Ecuador between 1990 and 2005 -- , and similarly to have a declining middle class and declining inequality.
} 
Countries of all political stripes in Latin America enjoyed a reduction in inequality in the 2000s. Nonetheless, the region continues to be the most unequal one in the world, and while in the last decade social policy became more pro-poor, in most countries public spending continues to be neutral or regressive.

In this paper we show that there is more to the story, however. In some countries the politics of redistributive policy appears to be changing in a fundamental way, suggesting that in those countries at least the recent declines in inequality are likely to stick.

On the basis of our econometric analysis and our comparison of governance and other characteristics, we conclude that in the social democratic regimes at least (but not in the populist regimes), the inequality decline is the outcome of what might be called a structural change. In contrast, in the populist regimes our evidence indicates that the declines in inequality have been due more to good luck than to good policy; that in Argentina and Venezuela inequality levels fell from levels higher than they had been historically is consistent with the good luck explanation.

Our conclusion rests primarily on the evidence that the economic policies and programs of social democratic regimes have been clearly redistributive - perhaps because they have some political logic in open and growing economies reliant on and benefiting a growing middle class. In terms of broadly defined economic conditions in the 2000s, the difference between the two types of leftist regimes were not all that great. Over the period 1990-2008 both types of leftist regimes had, not surprisingly, higher government expenditures (as a percent of GDP) than non-leftist regimes (and the social democratic regimes actually had higher overall government expenditures than the populist regimes). They also had lower inflation and higher social spending as a percent of GDP (than populist and non-left regimes), though not markedly so.

At the same time, controlling for differences in economic policies and characteristics, the social democratic regimes were more effective in designing and managing social policies that were more redistributive to the poorest groups, while maintaining good - indeed somewhat better macroeconomic programs than the populist left regimes and indeed than the non-left regimes. They delivered the right combination of healthy growth, macroeconomic stability and social policies (including increased social spending and higher minimum wages as well as cash transfer programs for the poor), building on a foundation of increased education. In those countries, growth benefited most the bottom three quintiles, partly because high social spending was highly redistributive. At the same time, with rapid economic growth overall, the incomes of the top quintiles continued to grow in absolute terms, increasing the size and share of income of households in the middle class, i.e. enjoying income of at least $\$ 10$ a day. In the social democratic regimes, it appears to have been more attractive politically to deliver a combination of low inflation and social programs and spending targeted to the poor.

In short, what might be called a new redistributive politics in Brazil and Chile compared to Argentina and Venezuela is what distinguishes the two types of leftist regimes. 
In those settings, if those "politics" continue, ${ }^{33}$ inequality declines are likely to be sustained in the future - a good thing given that their levels of inequality are still high. For the more populist political regimes, we are less confident. Whether because of or independent of their political characteristics, their macroeconomic policies are beginning to deteriorate, and their institutions are viewed as delivering government that is less "effective" than are the social democratic governments.

\footnotetext{
${ }^{33}$ How political factors affect the economic policies that ultimately matter for inequality constitutes in itself a rich future research agenda. Lustig et.al (2011) set out in detail the analytic underpinnings of economic analysis of various individual redistributive programs and policies - a first step in political analysis of how those economic policies are shaped.
} 


\section{References}

Acemoglu, D., G. Ergorov, and K. Sonin (2010). “A Political Theory of Populism”, MIT, mimeo, August, Cambridge, MA.

Acemoglu, Daron and James A. Robinson (2010). "A Theory of Political Transitions," The American Economic Review, Vol. 91, No. 4 (Sep., 2001), 938-963.

Alvaredo, Facundo and Thomas Piketty (2010), "The Dynamics of Income Concentration in Developed and Developing Countries: A View from the Top," in Declining Inequality in Latin America: A Decade of Progress?, eds. Luis F. Lopez-Calva and Nora Lustig, Brookings Institution Press and UNDP.

Arnson, Cynthia with José Raúl Perales. (2007) The 'New Left' and Democratic Governance in Latin America. Washington, D.C.: Woodrow Wilson International Center for Latin American Studies. http://www.wilsoncenter.org/topics/pubs/NewLeftDemocraticGovernance.pdf

Barros, Ricardo and Mirela de Carvalho and Samuel Franco and Rosane Mendonca (2010). "Markets, the State, and the Dynamics of Inequality in Brazil," in Declining Inequality in Latin America: A Decade of Progress?, eds. Luis F. Lopez-Calva and Nora Lustig, Brookings Insitution Press and UNDP.

Behrman, Jere R. and Nancy Birdsall and Miguel Székely, 2007. "Economic Policy Changes and Wage Differentials in Latin America," in Economic Development and Cultural Change vol. 56, pages 57-97, Chicago: University of Chicago Press.

Birdsall, Nancy (2010). "The (Indispensable) Middle Class in Developing Countries; or The Rich and the Rest, Not the Poor and the Rest," CGD Working Paper No. 207, Washington DC: Center for Global Development.

Birdsall, Nancy and Augusto de la Torre, and Felipe Valencia Caicedo (2010). "The Washington Consensus: Assessing a Damaged Brand.” CGD Working Paper 213. Washington DC: Center for Global Development. http://www.cgdev.org/content/publications/ detail/1424155.

Birdsall, Nancy and Frederick Jaspersen (1997). Pathways to Growth: Comparing East Asia and Latin America. Washington DC: Inter-American Development Bank.

Clemens, Michael A. (2004). "The Long Walk to School: International education goals in historical perspective," CGD Working Paper No. 37, Washington DC: Center for Global Development.

Cornia, Giovanni Andrea (2010). "Income Distribution under Latin America's New Left Regimes", Journal of Human Development and Capabilities, Vol. 11, \#1, February. 
Davies, James and Susanna Sandstrom and Anthony Shorrocks and Edward N. Wolff (2006). "The World Distribution of Household Wealth,” World Institute for Development Economics Research of the United Nations University (UNU WIDER).

Dornbusch, R and S. Edwards (1991). The Macroeconomics of populism in Latin America, University of Chicago Press, Chicago IL.

Edwards, Sebastian (2009). "Latin America's Decline: A Long Historical View," NBER Working Paper 15171, Cambridge: National Bureau of Economic Research.

Engerman, Stanley L. and Kenneth L.Sokoloff (1997). "Factor Endowments, Institutions, and Differential Paths of Growth Among New World Economies: A View from Economic Historians of the United States," in How Latin America Fell Behind, ed. Stephen Haber, Stanford: Stanford University Press.

Esquivel, Gerardo and Nora Lustig and John Scott (2010). "Mexico: A Decade of Falling Inequality: Market Forces or State Action," in Declining Inequality in Latin America: A Decade of Progress?, eds. Luis F. Lopez-Calva and Nora Lustig, Washington DC: Brookings Insitution Press and UNDP.

Gasparini, Leonardo and Guillermo Cruces (2010a). "A Distribution in Motion: The Case of Argentina," in Declining Inequality in Latin America: A Decade of Progress?, eds. Luis F. Lopez-Calva and Nora Lustig, Brookings Insitution Press and UNDP.

Gasparini, Leonardo and Guillermo Cruces (2010b). "Las Asignaciones Universales po Hijo: Impacto, Discusion u Alternativas," CEDLAS Working Paper No. 102, La Plata: Center for Distributive, Labor, and Social Studies, Universidad Nacional de La Plata.

Gasparini, Leonardo and Walter Sosa Escudero and Mariana Marchionni and Sergio Olivieri (2010). "Multidimensional poverty in Latin America and the Caribbean: New evidence from the Gallup World Poll," CEDLAS, Working Papers 0100, CEDLAS, Universidad Nacional de La Plata.

Gasparini, Leonardo and Nora Lustig (2010). "The Rise and Fall of Income Inequality in Latin America" in Handbook of Latin American Economics, Washington DC: Brookings Institution Press.

Gasparini, Leonardo and Guillermo Cruces and Leopoldo Tornarolli (2009). "Recent trends in income inequality in Latin America," Working Papers 132, ECINEQ, Society for the Study of Economic Inequality.

Goldin, Claudia and Lawrence F. Katz (2008). The Race Between Education and Technology, Cambridge: Harvard University Press.

Gray Molina, George, and Ernesto Yañez (2009). "The Dynamics of Inequality in the Best and Worst Times, Bolivia 1997-2007.” Discussion paper prepared for the UNDP Project Markets, the State and the Dynamics of Inequality: How to Advance Inclusive Growth, coordinated by Luis Felipe Lopez-Calva and Nora Lustig. (http://undp.economiccluster-lac.org/). 
Inter-American Development Bank (1999). "Facing Up to Inequality in Latin America," Economic and Social Progress in Latin America: 1998-1999 Report, Washington DC: Johns Hopkins University Press.

Jaramillo, Miguel and Jaime Saavedra (2010). "Inequality in Post-Structural Reform Peru: The Role of Market Forces in Public Policy," in Declining Inequality in Latin America: A Decade of Progress?, eds. Luis F. Lopez-Calva and Nora Lustig, Washington DC: Brookings Insitution Press and UNDP.

Kauffman, Daniel and Aart Kray and Massimo Mastruzzi (2008). "Governance Matters VII: Aggregate and Individual Governance Indicators 1996-2007,” Policy Research Working Paper 4654, Washington DC: World Bank.

Kauffman, Robert (2007). "Political Economy and the 'New Left"' in The New Left' and Democratic Governance in Latin America eds. Cynthia J. Arnson and Jose Raul Perales, Washington DC: Woodrow Wilson International Center for Scholars.

Lindert, Peter H. (2004). Growing Public: Social Spending and Economic Growth Since the Eighteenth Century, New York: Cambridge University Press.

Lindert, Peter H. and Jeffrey G. Williamson (2001). "Does Globalization Make the World More Unequal?,” NBER Working Paper 8228, Cambridge: National Bureau of Economics Research.

Lopez-Calva, Luis F., Nora Lustig and Eduardo Ortiz (2011). “The Recent Decline of Inequality in Latin America," Mimeo, Tulane University

Lopez-Calva, Louis F. and Nora Lustig (2010). Declining Inequality in Latin America: a Decade of Progress?, Brookings Institution Press and UNDP.

Lustig, Nora, Carola Pesssino and John Scott (2011). "A Diagnostic Framework to Assess Governments' Fiscal Policies on Social Equity: an Application to Argentina and Mexico.” Mimeo, Tulane University.

Lustig, Nora and Darryl McLeod. 2009. “Are Latin America’s New Left Regimes Reducing Inequality Faster? Addendum to Nora Lustig, 'Poverty, Inequality, and the New Left in Latin America" Washington: Woodrow Wilson International Center for Scholars (July).

Lustig, Nora (2000). "Crises and the Poor: Socially Responsible Macroeconomics", Economia, A Journal of the Latin American and Caribbean Economic Association (LACEA), No. 1, Washington DC: Brookings Institution.

Lustig, Nora (1995). Coping with Austerity: Poverty and Inequality in Latin America, Washington DC: Brookings Institution.

McLeod, Darryl and Nora Lustig (2010). "Poverty and Inequality under Latin America's New Left Regimes," Paper prepared for the $15^{\text {th }}$ Annual LACEA Meeting, Medellin, Colombia: Universidad de Antioquia and Universidad Eafit. 
McLeod, Darryl and Nora (2011) "Falling inequality under Latin America's New Left Regimes: who benefits?" mimeo, Fordham and Tulane University.

Morley, Samuel A. (2001). The income distribution problem in Latin America and the Caribbean, Economic Commission for Latin America and the Caribbean, United Nations.

Pages, Carmen and Gaelle Pierre and Stefano Scarpetta (2008). Job Creation in Latin America and the Caribbean: Recent Trends and Policy Challenges, Washington DC: World Bank Publications.

Roberts, Kenneth and Leslie Bethell and Rene Antonio Mayorga (2007). "Conceptual and Historical Perspectives" in The New Left' and Democratic Governance in Latin America eds. Cynthia J. Arnson and Jose Raul Perales, Washington DC: Woodrow Wilson International Center for Scholars.

Robinson, James A. (2010). "The Political Economy of Redistributive Policies" in Declining Inequality in Latin America: A Decade of Progess?, eds. Luis F. Lopez-Calva and Nora Lustig (p.39-71), Washington DC: Brookings Institution Press and UNDP.

Rodrik, Dani (1997). “Democracy and Economic Performance," unpublished paper, Harvard University.

Sachs, Jeffrey D. (1989). "Social Conflict and Populist Policies in Latin America," NBER Working Paper No. 2897, Cambridge: National Bureau of Economics Research.

Szekely, Miguel and Marianne Hilgert (1999). "What's Behind the Inequality We Measure: An Investigation Using Latin American Data," Research Department Working Paper \#409, Washington DC: Inter-American Development Bank.

Tinbergen, Jan (1975). Income Differences: Recent Research. Amsterdam: North Holland. 
Figure 1: Change in Gini Coefficients for Latin America: 2000-2008

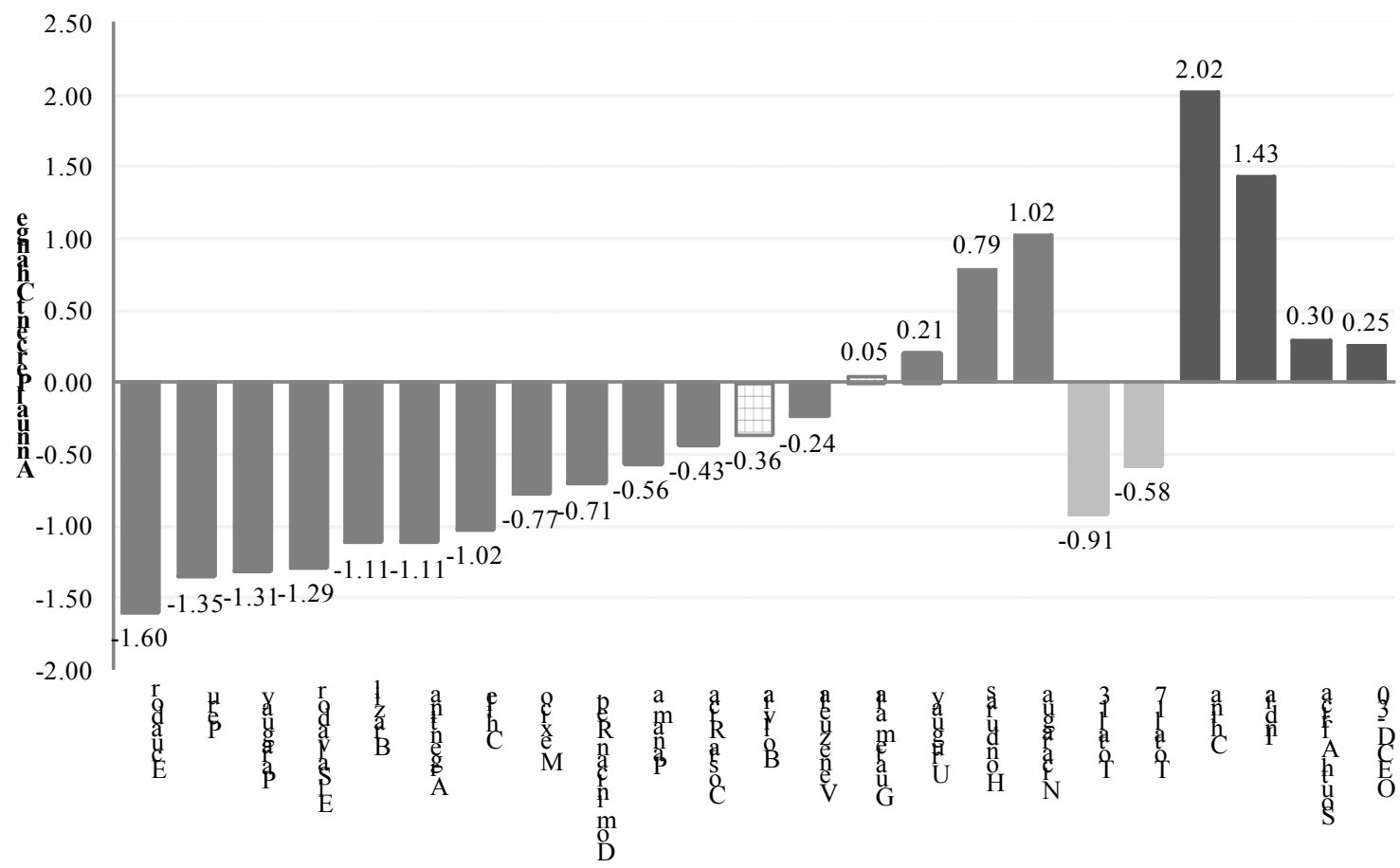

Source: updated from Lopez-Calva, Lustig and Ortiz (2011). Based on SEDLAC (CEDLAS and The World Bank), August 2010 (http://sedlac.eco....unlp.edu.ar/eng/)

Note: The bars in grey mean that the change was not statistically significant.

Data for Argentina and Uruguay are for urban areas only. In Uruguay, urban areas covered by the survey represent 80 percent of the total population; in Argentina, they represent 66 percent. The average change in the Gini for each country is calculated as the percentage change between the end year and the initial year divided by the number of years; the average for the total is the simple average of the changes by country (thirteen countries in which inequality fell). The years used to estimate the percentage change are as follows: Argentina (2008-00), Bolivia (2007-01), Brazil (2008-01), Chile (2006-00), Costa Rica (2008-01), Dominican Republic (2008-00), Ecuador (2008-03), El Salvador (2008-00), Guatemala (2006-00), Honduras (2007-01), Mexico (2008-00), Nicaragua (2005-01), Panama (2006-01), Paraguay (2008-02), Peru (2008-01), Uruguay (2008-00), and Venezuela (2006-00). Using the bootstrap method, with a 95 percent significance level, the changes were not found to be statistically significant for the following countries: Bolivia and Guatemala (represented by grid bars in the figure). The years used in non-Latin American countries are as follows: China (1993-Mid 00s), India (1993-Mid 00s), South Africa (1993-08), and OECD-30 (Mid 80sMid 00s). 
Figure 2: Gini coefficients for countries around the world

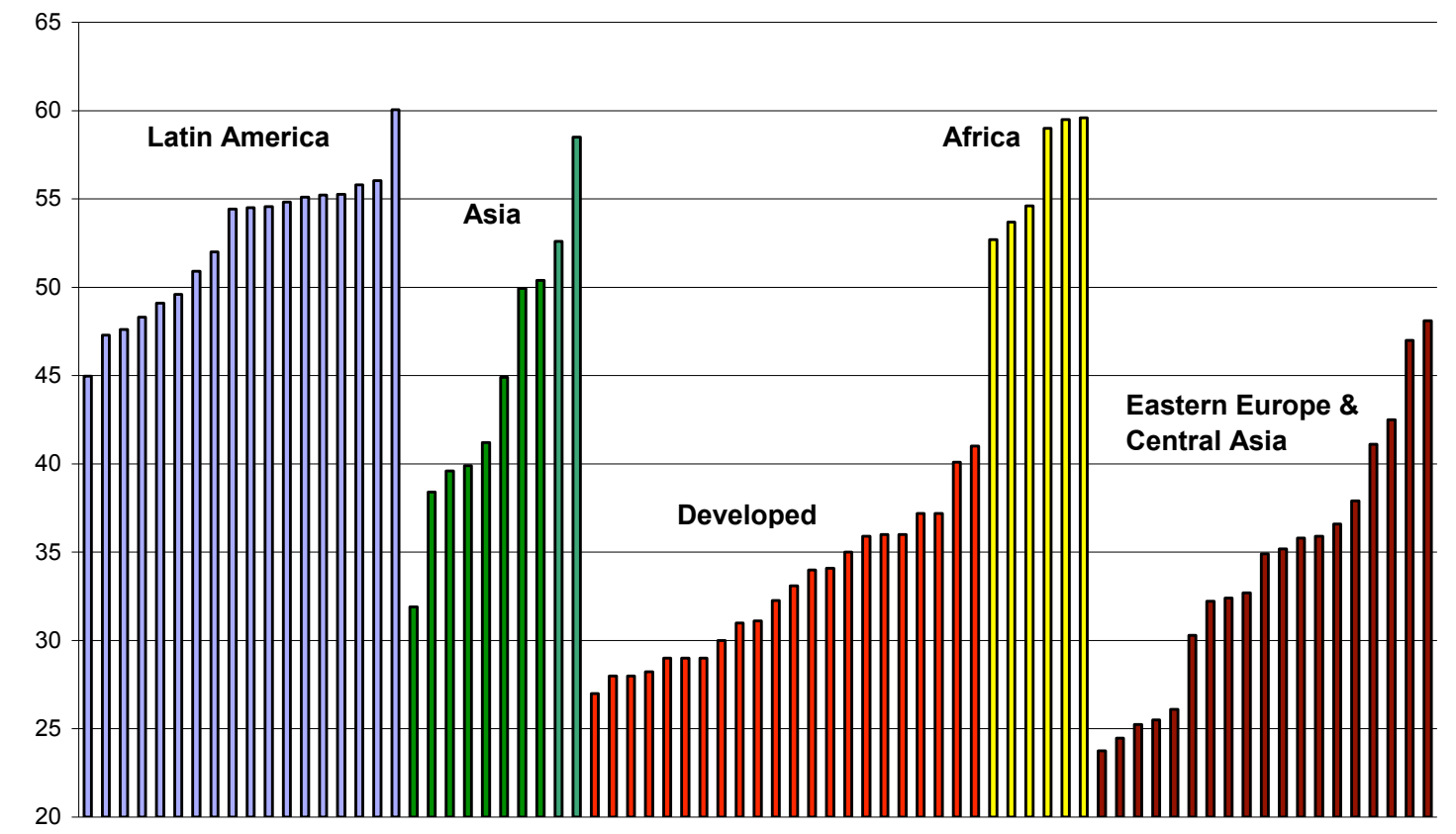

Source: Gasparini and Lustig (2010).

Note: Each bar represents the Gini coefficient for the distribution of household per capita income in a given country (last available observation in period 1995-2005). 
Figure 3: Comparison of $\mathbf{9 0 \%}$ Gini vs. total Gini in Latin America

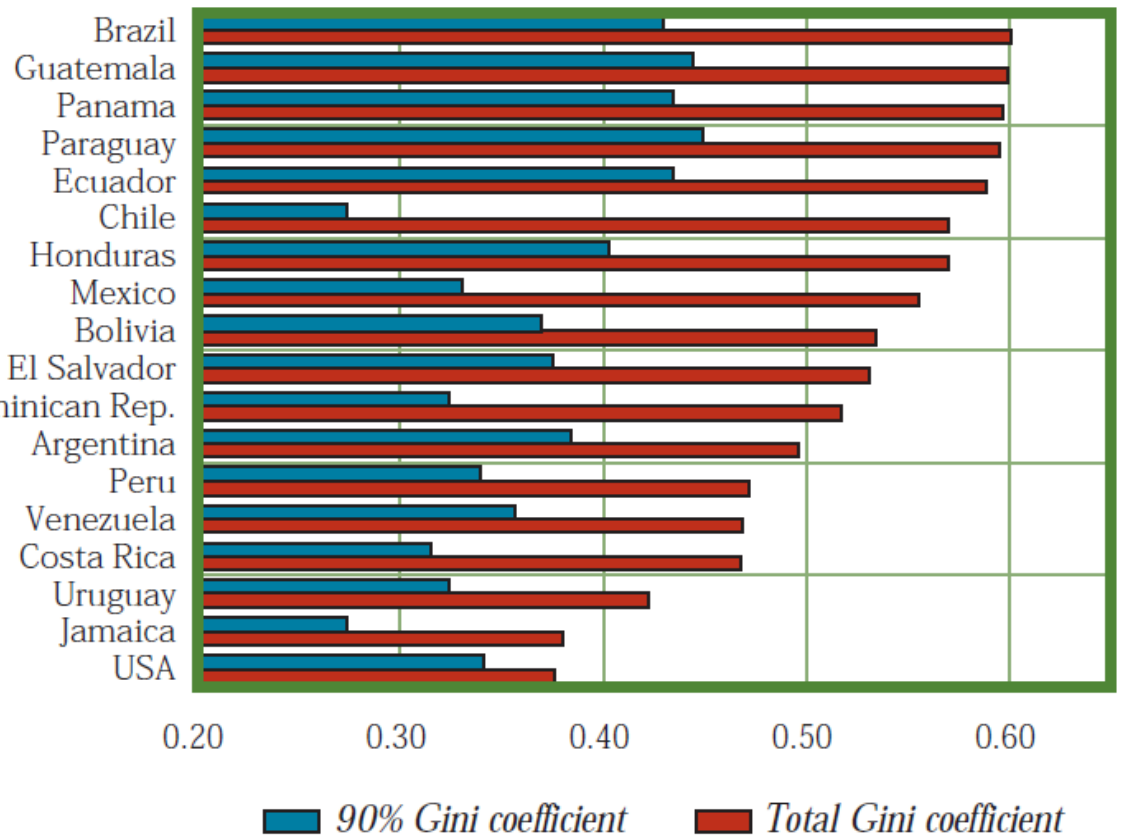

Source: Inter-American Development Bank (1999).

Note: From IDB calculations based on household surveys.

\section{Figure 4: The Education Gap}

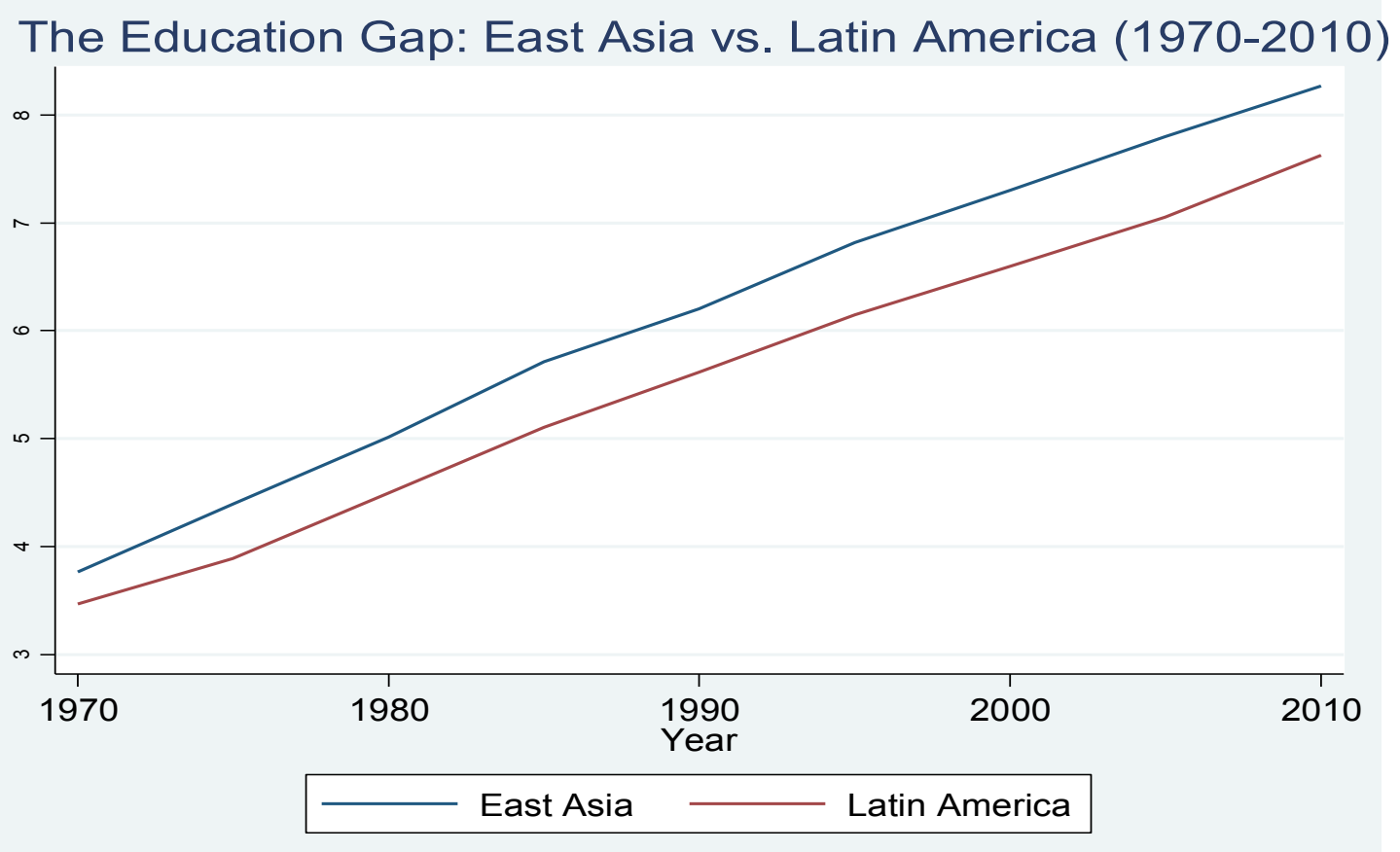

Source: Barro and Lee (2010) available at http://www.barrolee.com/. The East Asia group excludes small island economies, Laos, and Myanmar. 
Figure 5: Inequality in Argentina, Brazil, Chile, and Venezuela (Gini coefficients, rounded)
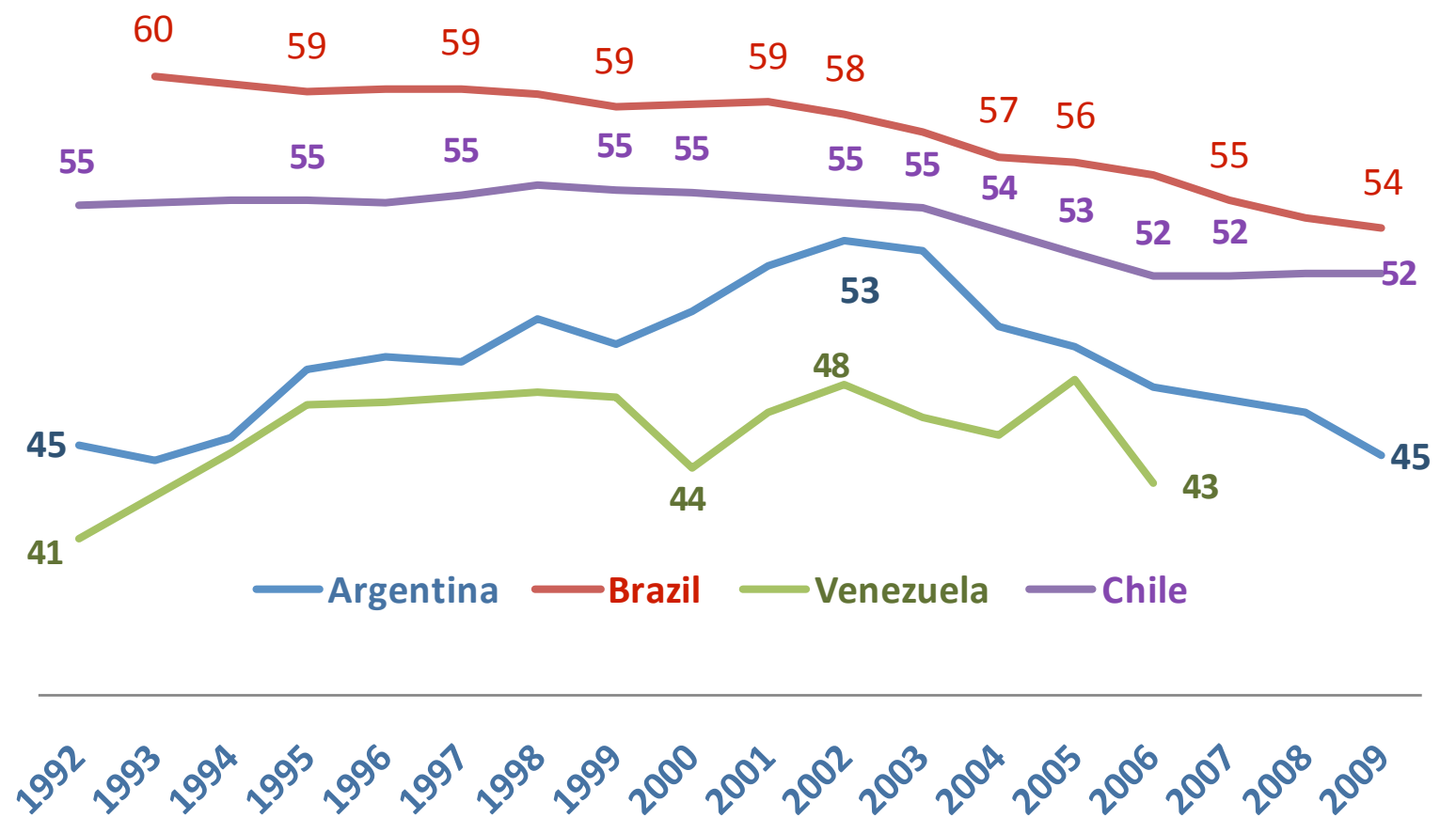

Source: SEDLAC (CEDLAS and the World Bank) as downloaded December 2010.

Source: McLeod and Lustig (2010).

Figure 6: Annual income redistribution by quintile (cumulative years in office starting in year 2)

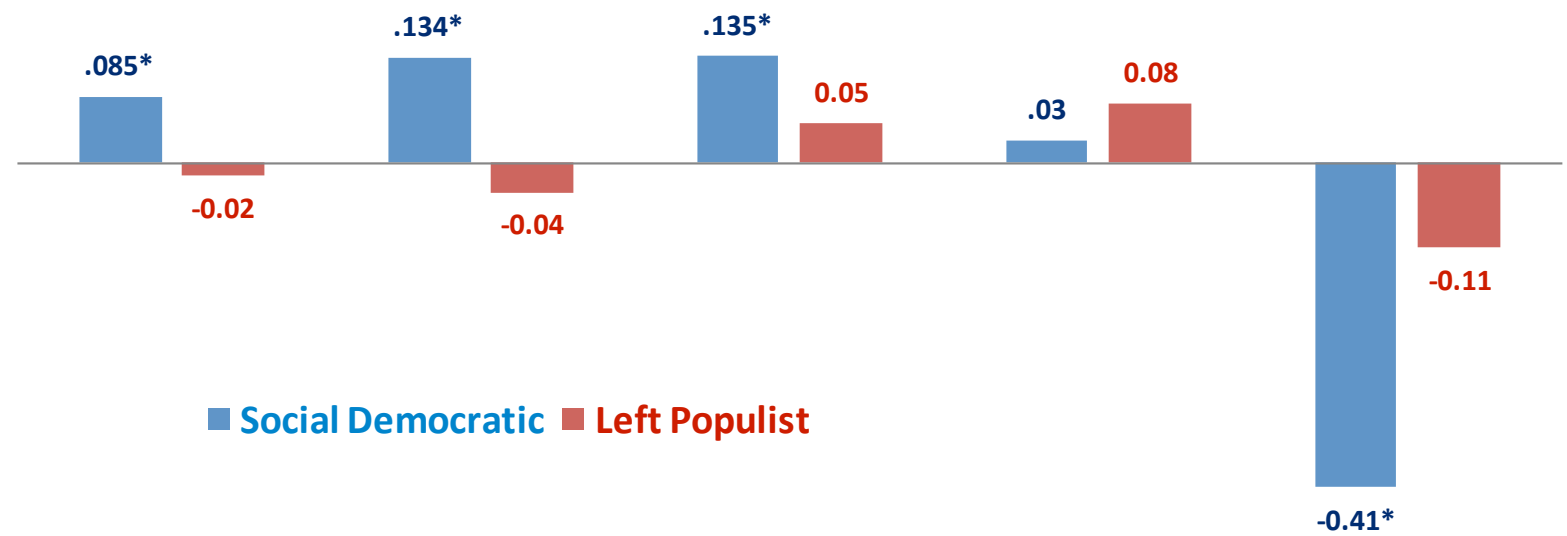

1st Quintile 2nd Quintile 3rd Quintile 4th Quintile $\quad$ 5th Quintile

*significant at $5 \%$ level, random effects estimates, see appendix A Table A-2 and McLeod and Lustig (2011). 
Figure 7: Latin American public spending on social programs as \% of GDP (education, health, and transfers)
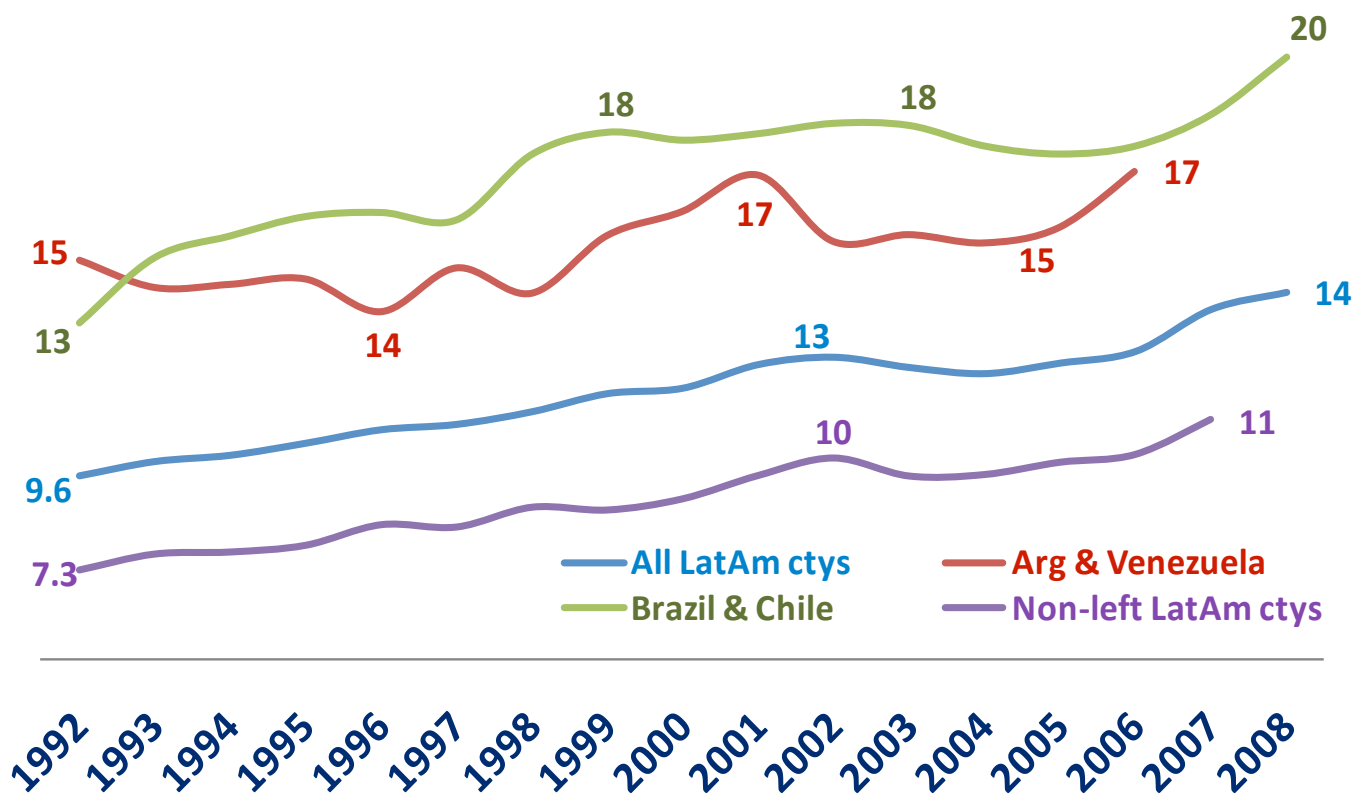

Source: Unweighted average for each group. CEPAL - CEPALSTAT, Estadísticas E Indicadores Sociales, Gasto público social, downloaded December, 2010 websie.eclac.cl/infest/ajax/cepalstat.asp? carpeta=estadisticas

Source: McLeod and Lustig (2010).

Figure 8: Redistributive impact of changes in social spending budget share by quintile (change significant at $* 5 \%$ or $* * 1 \%$ level)

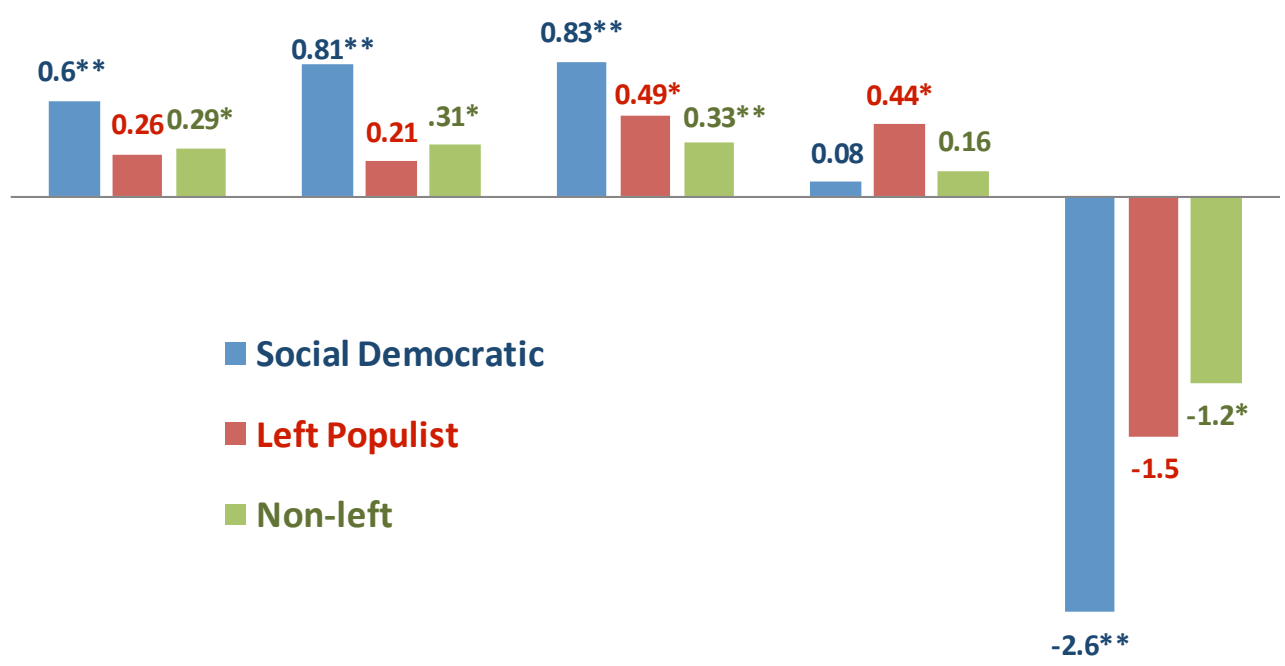

1st Quintile 2nd Quintile 3rd Quintile 4th Q 5th Quintile

Source: Appendix A, Table A-3 and McLeod and Lustig (2011). 
Figure 9: Government Effectiveness by political regime types (2000-2007)

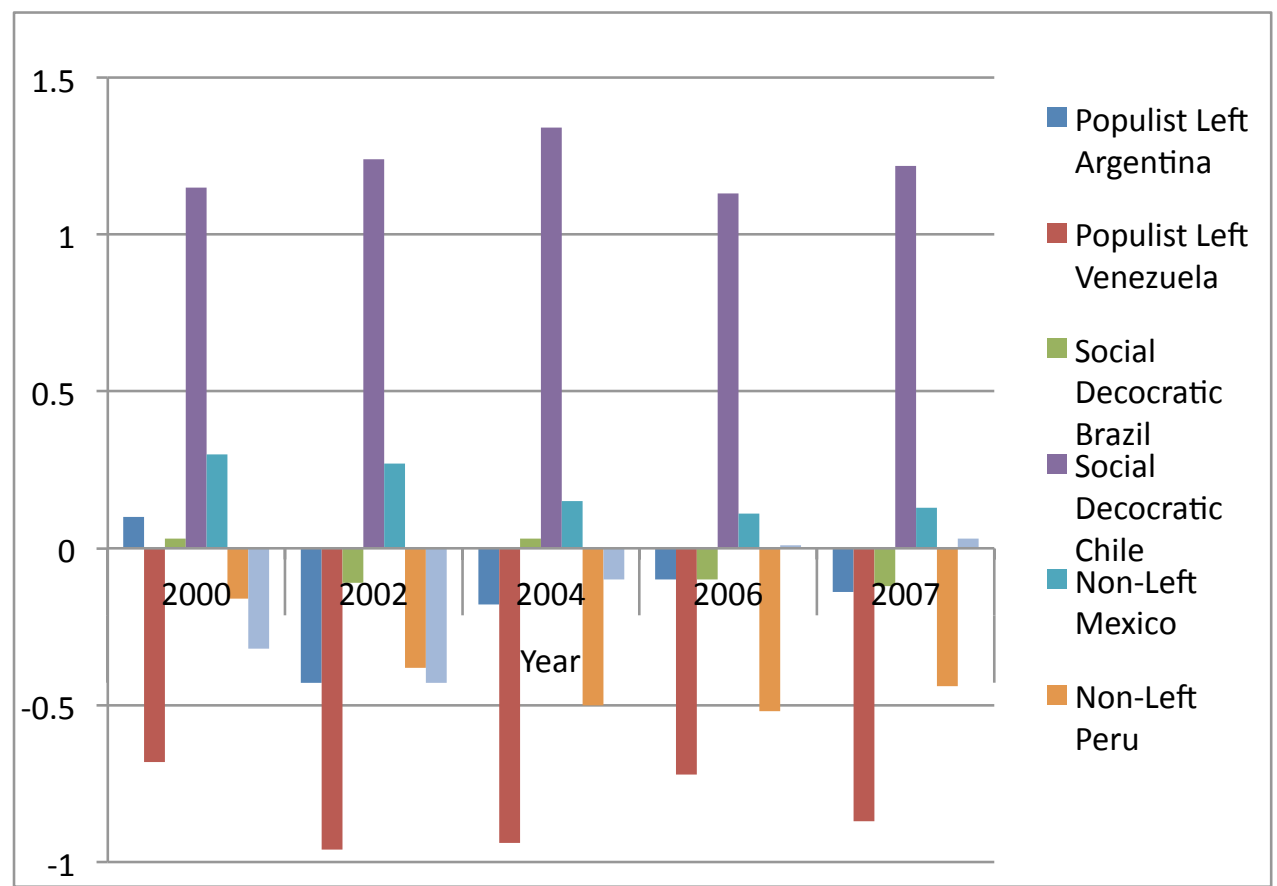

Source: Kaufmann and Kraay (2008)

Figure 10: Average Terms of Trade (2002-2006)

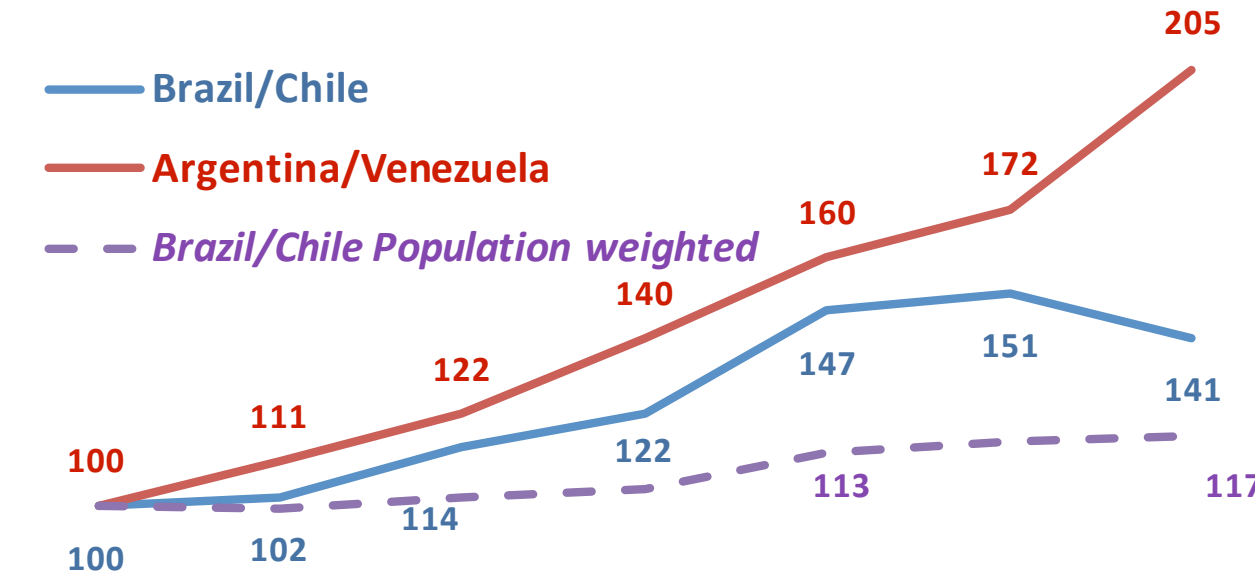

$\begin{array}{lllllll}2002 & 2003 & 2004 & 2005 & 2006 & 2007 & 2008\end{array}$

Source: CEPAL Database December 2010 
Figure 11: Change in Middle Class Size (proportion of population) between 1990 and 2005

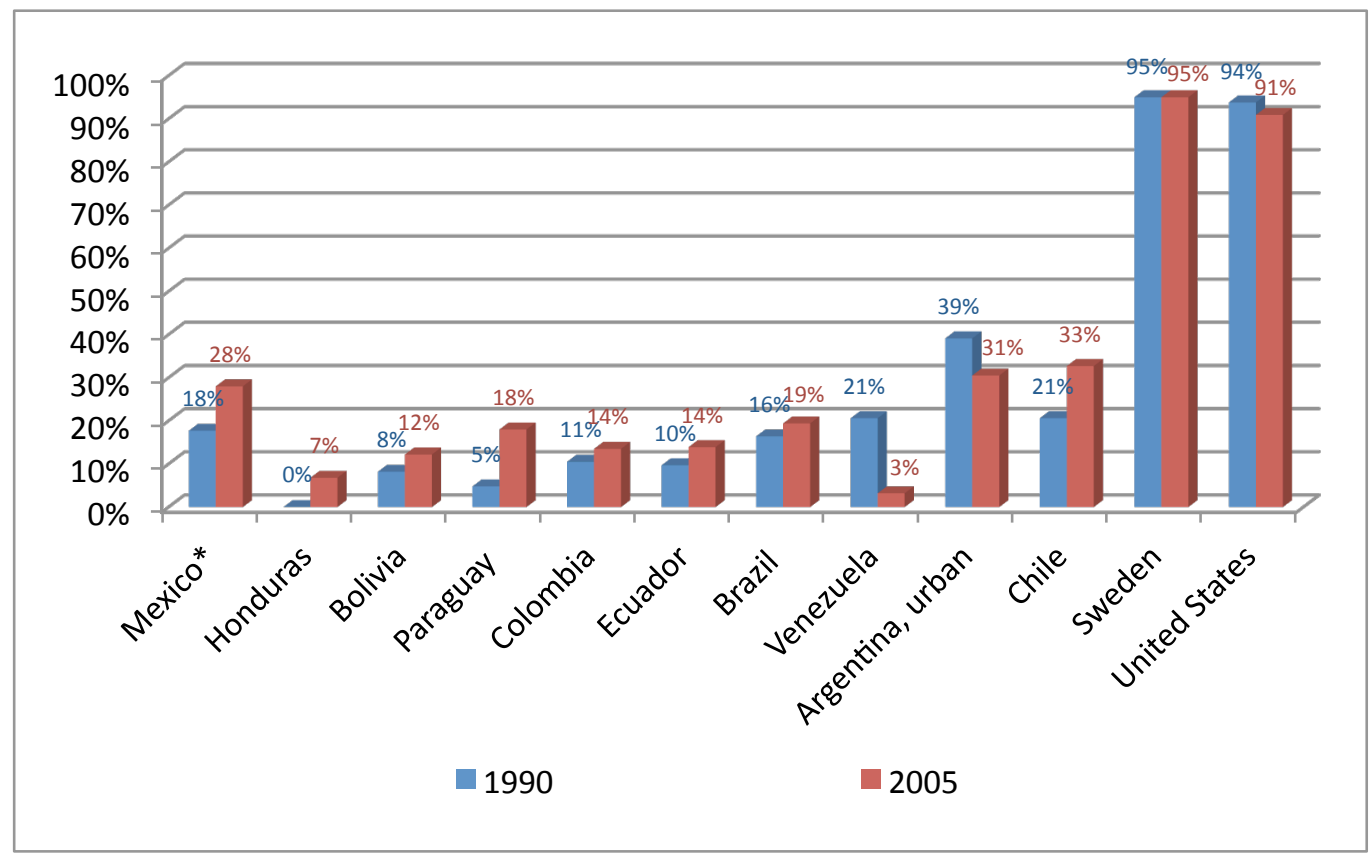

Source: Birdsall (2010) 


\section{Table 1: New Left Political Regimes in Latin America}

\begin{tabular}{|c|c|c|c|c|c|c|c|}
\hline \multirow[b]{2}{*}{ Country } & \multirow[b]{2}{*}{ Leader } & \multirow[b]{2}{*}{$\begin{array}{l}\text { Took } \\
\text { Office }\end{array}$} & \multirow[b]{2}{*}{$\begin{array}{c}\text { Effective } \\
\text { year* }\end{array}$} & \multirow[b]{2}{*}{ Classification $^{1 /}$} & \multicolumn{3}{|c|}{$\begin{array}{l}\text { Cumulative years } \\
\text { regime is in power* }\end{array}$} \\
\hline & & & & & $\begin{array}{l}2000- \\
2002\end{array}$ & $\begin{array}{l}2003- \\
2005\end{array}$ & $\begin{array}{l}2006- \\
2008\end{array}$ \\
\hline Argentina & The Kirchners & May-03 & 2004 & Left Populist & 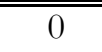 & 2 & 5 \\
\hline Bolivia & Evo Morales & Jan-06 & 2007 & Left Populist & 0 & 0 & 2 \\
\hline Brazil & Lula da Silva & Jan-03 & 2004 & $\begin{array}{c}\text { Social } \\
\text { Democratic }\end{array}$ & 0 & 2 & 5 \\
\hline Chile & Ricardo Lagos & Mar-00 & 2001 & $\begin{array}{c}\text { Social } \\
\text { Democratic }\end{array}$ & 2 & 5 & 8 \\
\hline Ecuador & Rafael Correa & Jan-07 & 2008 & Left Populist & 0 & 0 & 1 \\
\hline Nicaragua & Daniel Ortega & Jan-07 & 2008 & Left Populist & 0 & 0 & 1 \\
\hline Uruguay & $\begin{array}{l}\text { Tabaré } \\
\text { Vázquez }\end{array}$ & Mar-05 & 2006 & $\begin{array}{c}\text { Social } \\
\text { Democratic }\end{array}$ & 0 & 0 & 3 \\
\hline Venezuela & Hugo Chavez & Feb-99 & 2000 & Left Populist & 3 & 6 & 9 \\
\hline Total e & ective years & & & & 5 & 15 & 34 \\
\hline
\end{tabular}

Source: McLeod and Lustig (2010).

*'Effective year" is one year after the government takes office, as new policies take time to implement. Both Nicaragua and Ecuador elected left populist governments in 2008, outside the window of the present analysis.

$1 /$ This table begins with the political regime classification discussed in Arnson and Perales (2007). After 2007 left populist governments took office in Ecuador (Rafael Correa) and Nicaragua (Daniel Ortega). As Acemoglu et al. (2010, p. 1) notes the "resurgence of populist politicians in many developing countries, especially in Latin America. Hugo Chavez in Venezuela, the Kirchners in Argentina, Evo Morales in Bolivia, Alan Garcia in Peru, and Rafael Correa in Ecuador are examples of politicians that "use the rhetoric of aggressively defending the interests of the common man against the privileged elite." Unfortunately, Nicaragua could not be included among the left populist countries in the regression analysis because its data end in 2006. 
Table 2: Determinants of Latin American Inequality 1990-2008 (as measured by the Gini coefficient, including fixed effects)

\begin{tabular}{|c|c|c|c|}
\hline \multirow{3}{*}{$\begin{array}{c}\text { 3 year panel } \\
\text { Dependent Variable: } \\
\text { (t-statistics in parentheses) }\end{array}$} & \multicolumn{3}{|c|}{ with fixed effects ${ }^{1 /}$} \\
\hline & Gini & Coeffi & cient \\
\hline & I & II & III \\
\hline $\begin{array}{c}\text { Social Democratic Regime (years) } \\
\text { or cumulative years in office }\end{array}$ & $\begin{array}{r}-0.40 \\
-(2.7)\end{array}$ & $\begin{array}{l}-1.31 \\
-(3.2)\end{array}$ & $\begin{array}{r}-1.42 \\
-(4.1)\end{array}$ \\
\hline $\begin{array}{l}\text { Left-Popu list Regime (y ears in office) } \\
\text { or cumulative years in office }\end{array}$ & $\begin{array}{r}-\mathbf{0 . 1 4} \\
-(0.7)\end{array}$ & $\begin{array}{l}\mathbf{0 . 4 7} \\
(0.8)\end{array}$ & $\begin{array}{r}\mathbf{0 . 1 1} \\
(0.2)\end{array}$ \\
\hline Government Consp (log \% GDP) & $\begin{array}{c}6.2 \\
(3.7)\end{array}$ & & $\begin{array}{c}\mathbf{5 . 0} \\
(2.4)\end{array}$ \\
\hline Public Social Spending (log \% GDP) & $\begin{array}{c}-2.4 \\
-(1.7)\end{array}$ & & $\begin{array}{l}-3.2 \\
-(2.2)\end{array}$ \\
\hline Per capita in come \$ppp 2005 (log) & $\begin{array}{c}1.0 \\
(0.3)\end{array}$ & $\begin{array}{c}-3.6 \\
-(1.1)\end{array}$ & $\begin{array}{r}-1.8 \\
-(0.6)\end{array}$ \\
\hline Inflation rate (average CPI change) & $\begin{array}{l}\mathbf{0 . 2 3} \\
(2.9)\end{array}$ & & \\
\hline Net barter terms of trade (log) & & $\begin{array}{c}-4.6 \\
-(2.4)\end{array}$ & $\begin{array}{r}-3.0 \\
-(1.4)\end{array}$ \\
\hline Remitances/GDP & & $\begin{array}{l}-0.19 \\
-(3.0)\end{array}$ & $\begin{array}{l}-\mathbf{0 . 1 8} \\
-(2.8)\end{array}$ \\
\hline Merchandise Exports \% of GDP & & $\begin{array}{c}-3.5 \\
-(1.8)\end{array}$ & $\begin{array}{c}-3.1 \\
-(2.1)\end{array}$ \\
\hline Fuel exports \% of merchan dise exports & & $\begin{array}{l}\mathbf{0 . 6 0} \\
(3.5)\end{array}$ & $\begin{array}{l}\mathbf{0 . 6 3} \\
(3.4)\end{array}$ \\
\hline Constant & $\begin{array}{c}34 \\
(1.2)\end{array}$ & $\begin{array}{r}119 \\
(4.2) \\
\end{array}$ & $\begin{array}{r}88 \\
(2.7) \\
\end{array}$ \\
\hline Number of Observations & 85 & 80 & 80 \\
\hline Number of Countries 2/ & 17 & 17 & 17 \\
\hline Adjusted $\mathrm{R}^{2}$ & 0.80 & 0.78 & 0.80 \\
\hline Std Error of Regression & 2.1 & 2.2 & 2.1 \\
\hline $\begin{array}{l}\text { Cross-section/period fixed effects redundancy } F \text { test } \\
\text { prob value for fixed effects F-test (joint period/cross section) }\end{array}$ & $\begin{array}{r}6.7 \\
(0.0) \\
\end{array}$ & $\begin{array}{r}7.9 \\
(0.0) \\
\end{array}$ & $\begin{array}{r}5.7 \\
(0.0) \\
\end{array}$ \\
\hline
\end{tabular}

Source: Lustig and McLeod (2009) 
Table A-1: Key Economic Indicators by Political Regime: 1988-2009 (3 year averages)

\begin{tabular}{|c|c|c|c|c|c|c|c|c|}
\hline & $\begin{array}{c}1988- \\
90 \\
\end{array}$ & $\begin{array}{c}1991- \\
93 \\
\end{array}$ & $\begin{array}{c}1994- \\
96 \\
\end{array}$ & $\begin{array}{c}1997- \\
99 \\
\end{array}$ & $\begin{array}{c}2000- \\
02 \\
\end{array}$ & $\begin{array}{c}2003- \\
05 \\
\end{array}$ & $\begin{array}{c}2006- \\
08 \\
\end{array}$ & 2009 \\
\hline & \multicolumn{8}{|c|}{ Inflation (\% change in CPI) ${ }^{2 /}$} \\
\hline Social Democratic & 580 & 581 & 22 & 5.4 & 8.5 & 5.0 & 5.8 & 4.5 \\
\hline Left Populist & 1100 & 25 & 23 & 20 & 12 & 8.4 & 14 & 11 \\
\hline \multirow[t]{2}{*}{ Other Latam } & 447 & 456 & 14 & 3.6 & 4.7 & 4.4 & 5.7 & 4.2 \\
\hline & \multicolumn{8}{|c|}{ Average per capita GDP Growth } \\
\hline Social Democratic & 0.7 & 4.5 & 3.5 & 0.2 & -0.2 & 4.0 & 3.2 & -0.5 \\
\hline Left Populist & 3.1 & 1.8 & 1.4 & -1.4 & -1.4 & 5.6 & 2.0 & -1.5 \\
\hline \multirow[t]{2}{*}{ Other Latam } & 2.0 & 3.4 & 2.8 & 0.9 & 0.4 & 3.5 & 3.1 & -2.7 \\
\hline & \multicolumn{8}{|c|}{ Terms of Trade $(2000=100, W D I)$} \\
\hline Social Democratic & 109 & 101 & 113 & 110 & 99 & 106 & 126 & 124 \\
\hline Left Populist & 99 & 86 & 88 & 90 & 97 & 108 & 143 & 133 \\
\hline \multirow[t]{2}{*}{ Other Latam } & 97 & 92 & 103 & 103 & 98 & 97 & 103 & 100 \\
\hline & \multicolumn{8}{|c|}{ Government Consumption spending as a share of GDP (WDI) } \\
\hline Social Democratic & 15 & 16 & 18 & 18 & 19 & 19 & 20 & \\
\hline Left Populist & 12 & 12 & 12 & 13 & 14 & 14 & 15 & \\
\hline \multirow[t]{2}{*}{ Other Latam } & 6 & 7 & 8 & 9 & 10 & 10 & 11 & \\
\hline & \multicolumn{8}{|c|}{ Social Spending as a Share of GDP (CEPAL) ${ }^{1 /}$} \\
\hline Social Democratic & 13 & 13 & 14 & 14 & 15 & 14 & 14 & \\
\hline Left Populist & 7 & 9 & 11 & 13 & 13 & 13 & 12 & \\
\hline \multirow[t]{2}{*}{ Other Latam } & 10 & 9 & 10 & 11 & 12 & 12 & 11 & \\
\hline & \multicolumn{8}{|c|}{ Domestic Credit Growth \%change Dec/Dec } \\
\hline Social Democratic & & & & & 18 & 2.0 & 21 & -0.6 \\
\hline Left Populist & & & & & 12 & 12 & 17 & 17 \\
\hline Other Latam & & & & & 9.5 & 11 & 18 & 7.9 \\
\hline Addendum: & \multicolumn{8}{|c|}{ Domestic Credit Growth \%change Dec/Dec } \\
\hline Brazil \& Chile & & & & & 9 & 10 & 17 & 9.0 \\
\hline \multirow[t]{2}{*}{ Argentina \& Venezuela } & & & & & 27 & 20 & 32 & 31 \\
\hline & \multicolumn{8}{|c|}{ Inflation (\% change in CPI, IMF WEO) } \\
\hline Brazil \& Chile & 1105 & 580 & 364 & 4.9 & 5.4 & 5.9 & 5.0 & 7.4 \\
\hline \multirow[t]{2}{*}{ Argentina \& Venezuela } & 1380 & 53 & 38 & 18 & 13 & 16 & 18 & 27 \\
\hline & \multicolumn{8}{|c|}{ Average per capita GDP Growth } \\
\hline Brazil \& Chile & 0.4 & 4.2 & 4.2 & 0.6 & 1.1 & 3.5 & 1.9 & \\
\hline Argentina \& Venezuela & 4.0 & 2.5 & 1.8 & -1.9 & -4.5 & 9.2 & 2.8 & \\
\hline \multicolumn{9}{|c|}{$\begin{array}{l}\text { 1/ Social spending is not available for Bolivia, Venezuela or Ecuador in } 2007 \text { or } 2008 \text { so the } 2006 \\
\text { value is used for the 2006-08 period. Most other CEPAL social spending estimates end in } 2008 \text {. } \\
2 \text { / Changes in CPI are as reported by the IMF, WEO October } 2010 \text { database, except for } 2007 \text { to } \\
2009\end{array}$} \\
\hline
\end{tabular}


Table A-2: Changes in Quintile Share by Political Regime

Cumultive political regime years

\begin{tabular}{|c|c|c|c|c|c|c|c|}
\hline \multirow{3}{*}{$\begin{array}{l}\text { Dependent Variable: } \\
\text { Quintile share and Gini }\end{array}$} & \multicolumn{7}{|c|}{ Quintile shares } \\
\hline & Q1 & Q2 & Q3 & Q4 & Q5 & Q4* & Gini \\
\hline & A-2.1 & A-2.2 & A-2.3 & A-2.4 & A-2.5 & A-2.4a & A-2.6 \\
\hline $\begin{array}{l}\text { Left-Populist Regime } \\
\text { cumulative years in power }\end{array}$ & $\begin{array}{r}\mathbf{- 0 . 0 2} \\
-(0.3)\end{array}$ & $\begin{array}{r}\mathbf{- 0 . 0 4} \\
-(1.6)\end{array}$ & $\begin{array}{r}\mathbf{0 . 0 5} \\
(1.2)\end{array}$ & $\begin{array}{r}\mathbf{0 . 0 8} \\
(1.9)\end{array}$ & $\begin{array}{l}-\mathbf{0 . 1 1} \\
-(0.7) \\
-\end{array}$ & $\begin{array}{l}\mathbf{0 . 0 4} \\
(1.1)\end{array}$ & $\begin{array}{l}\mathbf{- 0 . 0 5} \\
-(0.2)\end{array}$ \\
\hline $\begin{array}{l}\text { Social Democratic Regime } \\
\text { cumulative years in power }\end{array}$ & $\begin{array}{l}\mathbf{0 . 0 9} \\
(7.6)\end{array}$ & $\begin{array}{l}\mathbf{0 . 1 3} \\
(2.9)\end{array}$ & $\begin{array}{l}\mathbf{0 . 1 4} \\
(3.8)\end{array}$ & $\begin{array}{r}\mathbf{0 . 0 3} \\
(0.7)\end{array}$ & $\begin{array}{l}\mathbf{- 0 . 4 1} \\
-(4.4)\end{array}$ & $\begin{array}{l}\mathbf{0 . 1 0} \\
(2.8)\end{array}$ & $\begin{array}{l}\mathbf{- 0 . 4 2} \\
-(4.3)\end{array}$ \\
\hline Initial income share or Gini & $\begin{array}{l}\mathbf{0 . 6 1} \\
(4.2)\end{array}$ & $\begin{array}{r}\mathbf{0 . 7 6} \\
(6.1)\end{array}$ & $\begin{array}{l}\mathbf{0 . 6 8} \\
(7.9)\end{array}$ & $\begin{array}{r}\mathbf{0 . 7 0} \\
(9.1)\end{array}$ & $\begin{array}{l}\mathbf{0 . 6 7} \\
(7.1)\end{array}$ & & $\begin{array}{l}\mathbf{0 . 7 0} \\
(7.4)\end{array}$ \\
\hline $\begin{array}{l}\text { Constant } \\
\text { (t-statistics in parentheses) }\end{array}$ & $\begin{array}{l}1.25 \\
(2.4)\end{array}$ & $\begin{array}{c}\mathbf{1 . 7} \\
(1.7)\end{array}$ & $\begin{array}{c}3.8 \\
(3.7)\end{array}$ & $\begin{array}{c}6.0 \\
(3.9)\end{array}$ & $\begin{array}{c}19 \\
(3.4)\end{array}$ & $\begin{array}{c}\mathbf{2 0} \\
(2.7)\end{array}$ & $\begin{array}{c}16 \\
(3.3)\end{array}$ \\
\hline Estimation method & $R E$ & $R E$ & $R E$ & $R E$ & $R E$ & $F E$ & $R E$ \\
\hline Number of Obs ervations & 96 & 96 & 96 & 96 & 96 & 96 & 96 \\
\hline Number of Countries 1/ & 17 & 17 & 17 & 17 & 17 & 17 & 18 \\
\hline Weighted adjusted $\mathrm{R}^{2}$ & 0.18 & 0.29 & 0.40 & 0.55 & 0.49 & 0.49 & 0.35 \\
\hline Unweighted $\mathrm{R}^{2}$ & 0.45 & 0.62 & 0.65 & 0.64 & 0.64 & & 0.33 \\
\hline Std Error of Regression & 0.50 & 0.56 & 0.61 & 0.61 & 0.72 & 0.72 & 2.31 \\
\hline Mean dependent variable & 3.4 & 7.2 & 12 & 20 & 57 & 20 & 52 \\
\hline Hausman test prob value & 0.92 & 0.33 & 0.36 & 0.02 & 0.49 & & 0.87 \\
\hline
\end{tabular}

* The null of unbiased random effects estimates is rejected for quintile 4 at the $2 \%$ significance level, equation A-2.4a provides unbiased fixed effects estimates.

1/ The quintile regressions exclude Uruguay, but the Gini equation A-2.6 includes Uruguay. Including Uruguay does not substantially alter the quintile results. 
Table A-3: Change in Quintile Shares, Random Effects Estimates Social spending as a share of total government cons umption

\begin{tabular}{lccccccc}
\hline & \multicolumn{7}{c}{ Quintile shares } \\
\cline { 2 - 8 } & Q1 & Q2 & Q3 & Q4 & Q5 & Gini & Gini \\
\cline { 2 - 8 } & $\mathbf{A - 3 . 1}$ & $\mathbf{A - 3 . 2}$ & $\mathbf{A - 3 . 3}$ & $\mathbf{A - 3 . 4}$ & $\mathbf{A - 3 . 5}$ & $\mathbf{A - 3 . 6}$ & $\mathbf{A - 3 . 7}$ \\
\hline \multirow{3}{*}{ Left-Populist Regime } & $\mathbf{0 . 2 6}$ & $\mathbf{0 . 2 1}$ & $\mathbf{0 . 4 9}$ & $\mathbf{0 . 4 4}$ & $\mathbf{- 1 . 5}$ & $\mathbf{- 1 . 7}$ & $\mathbf{- 2 . 2}$ \\
& $(1.1)$ & $(0.8)$ & $(2.0)$ & $(1.9)$ & $-(1.8)$ & $-(1.7)$ & $-(2.3)$ \\
Social Democratic Regime & $\mathbf{0 . 5 9}$ & $\mathbf{0 . 8 1}$ & $\mathbf{0 . 8 3}$ & $\mathbf{0 . 0 8}$ & $\mathbf{- 2 . 6}$ & $\mathbf{- 3 . 1}$ & $\mathbf{- 3 . 1}$ \\
& $(3.7)$ & $(4.2)$ & $(3.7)$ & $(0.4)$ & $-(3.5)$ & $-(3.6)$ & $-(4.3)$ \\
Non-left regimes & $\mathbf{0 . 2 9}$ & $\mathbf{0 . 3 1}$ & $\mathbf{0 . 3 3}$ & $\mathbf{0 . 1 6}$ & $\mathbf{- 1 . 2}$ & $\mathbf{- 1 . 5}$ & $\mathbf{- 2 . 2}$ \\
& $(1.9)$ & $(2.1)$ & $(2.7)$ & $(1.7)$ & $-(2.4)$ & $-(2.3)$ & $-(3.9)$ \\
Initial income share/Gini & $\mathbf{0 . 5 6}$ & $\mathbf{0 . 7 2}$ & $\mathbf{0 . 6 4}$ & $\mathbf{0 . 6 7}$ & $\mathbf{0 . 6 3}$ & $\mathbf{0 . 6 0}$ & $\mathbf{0 . 5 7}$ \\
& $(3.5)$ & $(5.4)$ & $(6.8)$ & $(8.7)$ & $(6.1)$ & $(5.1)$ & $(4.5)$ \\
Inflation & & & & & & & $\mathbf{1 . 2}$ \\
Constant & & & & & & & $(3.2)$ \\
(t-statistics in parentheses) & $(2.1)$ & $(1.7)$ & $(3.6)$ & $(4.2)$ & $(3.7)$ & $(3.6)$ & 3.6 \\
\hline Estimation method & $R E$ & $R E$ & $R E$ & $R E$ & $R E$ & $F E$ & $R E$ \\
Number of Observations & 96 & 96 & 96 & 96 & 96 & 96 & 96 \\
Number of Countries 1/ & 17 & 17 & 17 & 17 & 17 & 17 & 17 \\
Weighted adjusted R ${ }^{2}$ & 0.19 & 0.29 & 0.39 & 0.52 & 0.34 & 0.28 & 0.28 \\
Unweighted R & & & & & & & \\
Std Error of Regression & 0.47 & 0.61 & 0.65 & 0.65 & 0.62 & 0.59 & 0.60 \\
Mean dependent variable & 0.49 & 0.55 & 0.60 & 0.73 & 2.06 & 2.30 & 2.26 \\
\hline
\end{tabular}

